\title{
Physico-chemical characterisation of material fractions in residual and source- segregated household waste in Denmark
}

Götze, Ramona; Pivnenko, Kostyantyn; Boldrin, Alessio; Scheutz, Charlotte; Astrup, T. Fruergaard

Published in:

Waste Management

Link to article, DOI:

10.1016/j.wasman.2016.05.009

Publication date:

2016

Document Version

Peer reviewed version

Link back to DTU Orbit

Citation (APA):

Götze, R., Pivnenko, K., Boldrin, A., Scheutz, C., \& Astrup, T. F. (2016). Physico-chemical characterisation of material fractions in residual and source-segregated household waste in Denmark. Waste Management, 54, 1326. https://doi.org/10.1016/j.wasman.2016.05.009

\section{General rights}

Copyright and moral rights for the publications made accessible in the public portal are retained by the authors and/or other copyright owners and it is a condition of accessing publications that users recognise and abide by the legal requirements associated with these rights.

- Users may download and print one copy of any publication from the public portal for the purpose of private study or research.

- You may not further distribute the material or use it for any profit-making activity or commercial gain

- You may freely distribute the URL identifying the publication in the public portal 


\title{
Physico-chemical characterisation of material fractions in residual and source-segregated household waste in Denmark
}

\author{
R. Götze ${ }^{1, *}$, K. Pivnenko, A. Boldrin, C. Scheutz, T. Fruergaard Astrup \\ 1) Department of Environmental Engineering, Technical University of Denmark, Miljoevej, Building 115, Kgs. \\ Lyngby, DK-2800, Denmark \\ *) Corresponding author: e-mail: rmog@env.dtu.dk
}

"NOTE: this is the author's version of a work that was accepted for publication in Waste Management journal. Changes resulting from the publishing process, such as peer review, editing, corrections, structural formatting, and other quality control mechanisms may not be reflected in this document. Minor changes may have been made to this manuscript since it was accepted for publication.

A definitive version is published in Waste Management 54, 13-26, http://dx.doi.org/10.1016/j.wasman.2016.05.009" 


\begin{abstract}
:
Physico-chemical waste composition data are paramount for the assessment and planning of waste management systems. However, the applicability of data is limited by the regional, temporal and technical scope of waste characterisation studies. As Danish and European legislation aims for higher recycling rates evaluation of source-segregation and recycling chains gain importance. This paper provides a consistent up-todate dataset for 74 physico-chemical parameters in 49 material fractions from residual and 24 material fractions from source-segregated Danish household waste. Significant differences in the physico-chemical properties of residual and source-segregated waste fractions were found for many parameters related to organic matter, but also for elements of environmental concern. Considerable differences in potentially toxic metal concentrations between the individual recyclable fractions within one material type were observed. This indicates that careful planning and performance evaluation of recycling schemes are important to ensure a high quality of collected recyclables. Rare earth elements (REE) were quantified in all waste fractions analysed, with the highest concentrations of REE found in fractions with high content of mineral raw materials, soil materials and dust. The observed REE concentrations represent the background concentration level in nonhazardous waste materials that may serve as a reference point for future investigations related to hazardous waste management. The detailed dataset provided here can be used for assessments of waste management solutions in Denmark and for the evaluation of the quality of recyclable materials in waste.
\end{abstract}

Keywords: municipal solid waste (MSW); chemical composition; recycling; rare earth elements (REE) 


\section{Introduction}

Physico-chemical waste composition data are paramount for i) quantifying substance flows of valuable and harmful components in the solid waste management sector, ii) for assessing the quality of waste materials and recyclables, and iii) for modelling emissions from waste treatment based on the composition of the incoming waste. For these purposes decision-support tools such as material flow analysis (MFA), substance flow analysis (SFA) and life cycle assessment (LCA) can be used. The fractional and physico-chemical waste composition has been shown to significantly affect the result of waste systems LCAs (Slagstad and Brattebø, 2013; Turconi et al., 2011). State-of-the-art environmental assessment of waste management systems should therefore comprise the tracking of material and substance flows in the modelled systems, a careful selection of waste composition data and an analysis of related uncertainties (Arena and Di Gregorio, 2014; Clavreul et al., 2012; Laurent et al., 2014). Thus, informed decisions on waste management strategies, e.g. the design of collection schemes or introduction of new treatment technologies, require reliable chemical waste composition data.

Several publications provide information on the physico-chemical composition of household waste material fractions (Gidarakos et al., 2006; Kost, 2001; Maystre and Viret, 1995; Riber et al., 2009; Rotter, 2002; Zhou et al., 2014). The physico-chemical properties of household waste are closely interlinked to the fractional waste composition, which is influenced by many varying aspects such as seasonal variation, regional customs and consumer behaviour, local waste collection schemes and their change with time (Boldrin and Christensen, 2010; Dahlén and Lagerkvist, 2008; Matsuto and Ham, 1990; Noehammer and Byer, 1997). But also the sampling point, the sorting of waste fractions, as well as mechanical sample preparation and analytical methods can affect the physico-chemical results (Brunner and Ernst, 1986; la Cour Jansen et al., 2004; Riber et al., 2009; Skutan and Aschenbrenner, 2012). As a consequence, the applicability of waste characterisation data is often limited by the regional, temporal and technical scope of the respective waste characterisation studies.

Physico-chemical waste composition data for Danish household waste materials can be found in Andersen et al. (2011), Boldrin and Christensen (2010), Fjelsted and Christensen (2007), Hansen et al. (2003), and Riber et al. (2009). The largest dataset is provided by Riber et al. (2009), who investigated 26 parameters in 47 waste material fractions in mixed household waste. For many years waste incineration with energy recovery has been the cardinal waste treatment technology for Danish household waste, but this is about to change as recent European legislation requires Denmark and all other EU member states to implement source-segregation schemes for the collection of recyclables in order to increase waste recycling rates (EU, 2008; The Danish Government, 2013). To ensure that source-segregation and recycling schemes do not shift environmental burdens to other parts of the waste management system, modelling and assessment of environmental impacts is becoming increasingly important. The definition of the waste material fractions in Riber et al. (2009) primarily reflected research questions focusing on waste incineration and energy recovery, which limits the applicability of these data in a recycling context. Thus data are needed for recyclable fractions distinguished by properties related to automated sorting and recycling processes (e.g. metals by ferrous and non-ferrous metals, and plastics by polymer resin).

The quality of waste materials may significantly affect recycling efficiencies, i.e. levels of the presence of contaminants and impurities may limit recyclability and substitution of virgin raw materials. When waste materials are collected mixed together, solid particles, moisture and dissolved substances can migrate from one waste material to another. This effect has been discussed in a waste management context as "crosscontamination" (Baeyens et al., 2010a; Edjabou et al., 2015; Miranda et al., 2013). Physico-chemical composition data for waste material fractions sampled from mixed waste collection may thus not appropriately represent the physico-chemical properties of the respective source-segregated materials. So far only organic waste materials from separate collection have been subject to physico-chemical characterisation in Denmark 
(Boldrin and Christensen, 2010; Hansen et al., 2003). Therefore, physico-chemical composition data for other source-segregated recyclables are needed.

The overall aim of this study is to provide a consistent dataset for the composition of individual material fractions in Danish household waste covering a wide range of physico-chemical properties, which can be used for future modelling and assessment of waste management systems and recycling chains. Based on waste samples from both residual and source-segregated household waste collected in the same area, the evaluation of the results of the physico-chemical characterisation focused on the following aspects: i) physico-chemical differences between subfractions within the same material type, especially for potentially recyclable materials; ii) potential differences between residual and source-segregated waste fractions, e.g. due to crosscontamination of materials. Based on this, conclusions on necessary levels of disaggregation of waste material fractioning are provided, to support the planning of future waste characterisation studies with similar purposes.

\section{Material and Methods}

\subsection{Collection area and sorting procedure}

All household waste samples, were collected in 2013 as part of a waste sorting campaign in Aabenraa, Denmark. The full-service waste collection scheme in place included a residual waste bin and a twocompartment bin for the source-segregation of recyclables. One compartment was designated for the collection of paper, cardboard and plastic foil, and the other compartment for packaging and non-packaging items made of metal and rigid plastics, and glass packaging. Hazardous waste, bulky waste and large amounts of garden waste were excluded from the full service collection and instead delivered to central collection facilities by the residents. Additionally, the national refund system for beverage containers (made of glass, plastic and metal) was in place. Detailed information on stratification areas, sorting procedure and the resulting fractional composition of the waste are provided in Edjabou et al. (2015). Although the initially collected waste samples were derived from both multi and single-family housing areas, the waste from single-family housing areas was selected for further physico-chemical characterisation. The analysed samples were obtained from 1.5 tonnes of residual waste and 0.9 tonnes of source-segregated waste, which was generated and disposed of by 100 households within a period of two weeks in spring 2013. The waste for the sorting campaign was collected without compacting, and sorted into and temporarily stored in paper sacks. As described by Edjabou et al. (2015), the hand-sorting procedure followed a tiered approach; the entire amount of collected waste was first hand-sorted into 10 defined macro fractions followed by subsequent sorting into 37 material fractions (see level I and II in Edjabou et al., 2015) and finally into 50 material fractions (see Table 1 and more details in Appendix B). The same procedure was applied to the collected waste from source-segregation. Batteries, waste electronics and hazardous waste fractions were excluded from the physico-chemical analysis due to the small amounts found in the investigated household waste, which was not suitable to represent the extensive variety of products matching these fractions. Table 1 provides an overview of the material fractions investigated; in total 49 material fractions from residual and 26 material fractions from source-segregated household waste were obtained. A more detailed description of sorted fractions is available in Appendix B.

\subsection{Mass and particle size-reduction}

Following the sorting, the material fractions from residual and source-segregated household waste were prepared for physico-chemical characterisation (see an overview in Figure 1). To homogenize the sorted material fractions each fraction was passed at least two times through a shredder (ARP SC2000, Brovst, 
Denmark) reducing the particle size and mixing the fractions' components. The maximum amount of material processed in the shredder was about $40 \mathrm{~kg}$. As the amounts of vegetable and animal derived food waste, and human hygiene waste were larger than $40 \mathrm{~kg}$, mass-reduction prior to the shredding was necessary for these fractions, which was performed by selecting only some of the paper sacks the material fractions were sorted into. For all other fractions the entire amount was shredded. Each fraction was processed separately and between the processing of different fractions the shredder was cleaned with water and compressed air. For further mass-reduction of the samples after the shredding, the shredded material was spread on a plastic foil on the ground and arranged in an elongated flat pile simulating a one-dimensional lot. Splitting elongated flat piles has been reported to decrease sampling errors relative to other mass reduction techniques such as coning and quartering (Dahlén and Lagerkvist, 2008; Gy, 1998; Lagerkvist et al., 2011; Petersen et al., 2004), and has been previously applied for the sampling of waste materials by Boldrin and Christensen (2010). The flat pile was split into equally sized increments by means of a large plastic box and a shovel, and every second increment was discarded, so that the sample mass was reduced by half. This procedure was repeated until a mass of approximately $0.5-1.5 \mathrm{~kg}$ of wet material was obtained. Degradable fractions with high moisture content; i.e. food and gardening waste fractions, and tissue paper from residual waste were first processed and then temporarily stored at $-18^{\circ} \mathrm{C}$ until drying them for $72 \mathrm{~h}$ at $60^{\circ} \mathrm{C}$. All other shredded material fractions were temporarily stored in paper sacks under dry conditions and at temperatures around $20^{\circ} \mathrm{C}$ until they were dried for $24 \mathrm{~h}$ at $105^{\circ} \mathrm{C}$. The dried samples were then further comminuted in a cutting mill (SM2000, Retsch, Germany). In case of brittle materials, i.e. glass, ceramics and soil, comminution by means of a jaw crusher and pulverization in a vibrating disc mill with an agate grinding set (TS.100A, Siebtechnik) was used instead. The fraction ceramics and porcelain (i1) was ground by means of a tungsten-carbide grinding set due to higher hardness. While the processing of thin-walled non-ferrous and ferrous metal packaging as well as non-ferrous metal non-packaging was manageable in the cutting mill, ferrous non-packaging metal included metal pieces which were too thick. Instead, the material was pressed to a pellet which was then drilled at different points, and the resulting turnings were used as sample material for physico-chemical analysis. The particle size reduction in the cutting mill took place in two steps; first a comminution of the particles to diameters passing a $4 \mathrm{~mm}$ sieve and secondly to diameters passing a $1 \mathrm{~mm}$ sieve. For plastics, textiles and metal fractions continuous cooling of the sample material and the cutting mill with liquid nitrogen was necessary to avoid melting of the sample material and damage of the equipment by overheating. When necessary the mass of the milled or ground samples was once more reduced by means of a riffle splitter (10x2 cm chutes) until a storage volume of maximum $1 \mathrm{~L}$ was obtained. The samples were stored in closed PET jars in a dry and dark environment until chemical analysis was performed.

The paper and cardboard waste fractions were also subject to further investigations of organic pollutants (not included in this article). For this purpose paper and cardboard was sorted into 30 different material fractions (Pivnenko et al., 2016). To better serve the purpose of this article, only aggregated results for eight material fractions are presented and discussed. Furthermore, the sample preparation procedure for paper and cardboard samples was adapted to avoid evaporation and migration of organic substances during drying and storage. Following the mass reduction, the coarsely shredded paper and board fractions were milled to particle sizes $\leq 4 \mathrm{~cm}$, split with a riffle splitter to a maximum storage volume of $1 \mathrm{~L}$, and then lyophilised and stored in

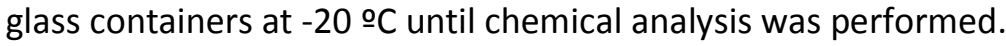




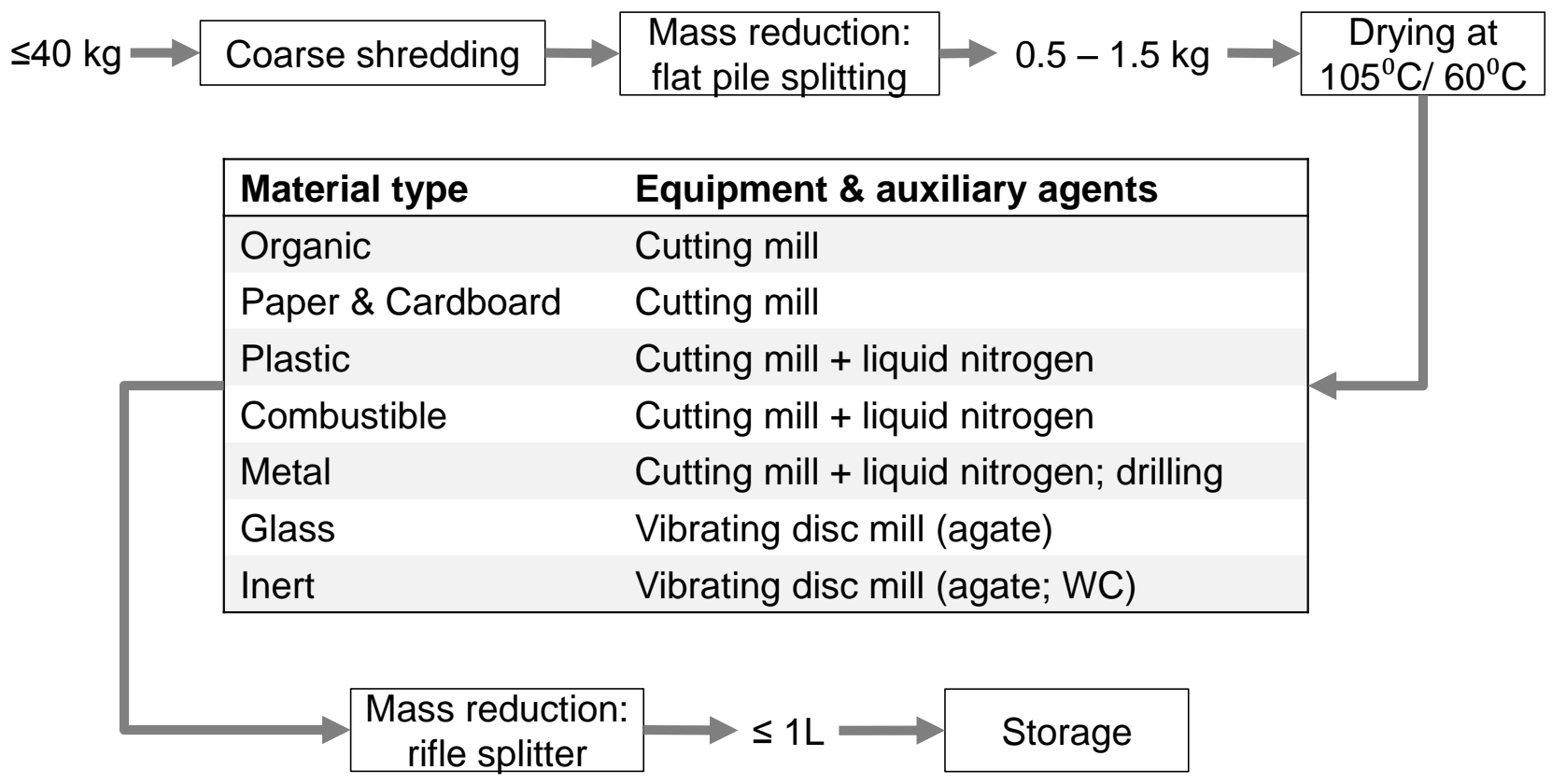

Figure 1 - Overview of analysed physical and chemical parameters and employed measurement techniques.

\subsection{Physico-chemical analysis}

\subsubsection{Energy and ash content}

For the determination of the ash content three replicates of $1 \mathrm{~g}$ of dry sample were heated sequentially until $550^{\circ} \mathrm{C}$ was reached and left at constant temperature for $2 \mathrm{~h}$, following the standardized procedures of EN 14775 (CEN, 2009). The higher heating value (HHV) of the dried samples was determined in triplicates by means of an oxygen bomb calorimeter following the standard EN 15400 (CEN, 2006). The lower heating value (LHV) was calculated based on the measured HHV and $\mathrm{H}$ content $\left(\mathrm{x}_{\mathrm{H}}\right)$ according to the equation presented in DIN 51900 (DIN, 2005):

$\operatorname{LHV}\left[\frac{k J}{k g T S}\right]=H H V\left[\frac{k J}{k g T S}\right]-2441 \times 9 \times x_{H}$.

The lower heating value of metal samples originating from organic materials, such as labels, organic lacquers and food residues, was estimated based on the measured contents of $\mathrm{C}, \mathrm{H}, \mathrm{N}, \mathrm{O}$ and $\mathrm{S}$ using the equation presented by Schwanecke (1976):

$L H V\left[\frac{k J}{k g w e t}\right]=348 \times C[\%]+939 \times H[\%]+105 \times S[\%]+63 \times N[\%]-108 \times O[\%]-24.5 \times H_{2} O[\%]$.

\subsubsection{Elemental composition}

The content of the elements $\mathrm{C}, \mathrm{H}, \mathrm{N}$, and $\mathrm{O}$ was analysed with an Elemental Analyser (MacroCube, Elementar) using at least three replicates. Halogens released during the combustion of the sample in the calorimetric bomb (for the determination of the energy content) were trapped in an absorption solution for subsequent 
analysis of $\mathrm{Cl}, \mathrm{Br}$, and $\mathrm{F}$ content via ion-chromatography following the standard EN 15408 (CEN, 2011); at least three replicates were analysed. The content of mercury $(\mathrm{Hg})$ was analysed in at least three replicates using a mercury analyser (based on thermal decomposition of the solid sample) following US EPA standard method 7473 (US EPA, 2007). The elemental contents of 64 metals, nutrients and trace elements (details in Figure 2) were analysed via ICP-MS (7700 series, Agilent) and ICP-OES (Vista-MPX, Varian) subsequent to microwave-assisted acid digestion of approximately $250 \mathrm{mg}$ of dry sample material. The ICP-MS was equipped with a collision cell using $\mathrm{He}$ as reactive cell gas, which was used for some elements when polyatomic interferences were observed (e.g. for As). For ICP-MS measurement $Y$ was used as an internal standard. The employed acid digestion methods aimed at total content analysis and were selected based on a prior method screening taking the specific properties of each waste material type into account (reported in Table 1). The acid digestion was performed in a microwave sample preparation system with temperature and pressure control (Multiwave 3000, Anton Paar). Each sample was digested in triplicates and for some samples additional replicates were prepared if necessary (e.g. if the results showed large variations or if large amounts of solids remained after the acid digestion).

\begin{tabular}{|c|c|c|c|c|c|c|c|c|c|c|c|c|c|c|c|c|c|}
\hline $\begin{array}{r}1 \\
\mathbf{H} \\
\end{array}$ & & & & \multicolumn{3}{|c|}{ HHV } & & & & & & & & & & & $\begin{array}{c}2 \\
\mathrm{He}\end{array}$ \\
\hline 3 & 4 & & & \multirow{2}{*}{\multicolumn{3}{|c|}{ ash content }} & & & & & & 5 & 6 & 7 & 8 & 9 & \\
\hline Li & $\mathrm{Be}$ & & & & & & & & & & & B & C & $\mathbf{N}$ & 0 & $\mathbf{F}$ & $\mathrm{Ne}$ \\
\hline 11 & $\overline{12}$ & & & & & & & & & & & 13 & $\overline{14}$ & 15 & $\overline{16}$ & 17 & 18 \\
\hline $\mathbf{N a}$ & Mg & & & & & & & & & & & Al & Si & $\mathbf{P}$ & $\mathbf{S}$ & Cl & Ar \\
\hline 19 & 20 & 21 & 22 & 23 & 24 & 25 & 26 & 27 & 28 & 29 & 30 & 31 & 32 & 33 & 34 & 35 & 36 \\
\hline K & $\mathbf{C a}$ & Sc & Ti & V & $\mathrm{Cr}$ & Mn & $\mathrm{Fe}$ & Co & $\mathrm{Ni}$ & $\mathrm{Cu}$ & $\mathbf{Z n}$ & Ga & $\mathrm{Ge}$ & As & $\mathrm{Se}$ & $\mathrm{Br}$ & $\mathrm{Kr}$ \\
\hline 37 & 38 & 39 & 40 & 41 & 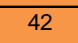 & 43 & 44 & 45 & 46 & 47 & 48 & 49 & 50 & 51 & 52 & 53 & 54 \\
\hline $\mathbf{R b}$ & $\mathrm{Sr}$ & $\mathbf{Y}$ & $\mathrm{Zr}$ & Nb & Mo & Tc & $\mathbf{R u}$ & Rh & Pd & $\mathrm{Ag}$ & Cd & In & Sn & Sb & $\mathrm{Te}$ & I & $\mathrm{Xe}$ \\
\hline 55 & 56 & & 72 & 73 & 74 & 75 & 76 & 77 & 78 & 79 & 80 & 81 & 82 & 83 & 84 & 85 & 86 \\
\hline Cs & $\mathbf{B a}$ & * & Hf & $\mathrm{Ta}$ & W & $\mathbf{R e}$ & Os & Ir & $\mathrm{Pt}$ & $\mathrm{Au}$ & $\mathrm{Hg}$ & TI & $\mathrm{Pb}$ & Bi & Po & At & Rn \\
\hline 87 & 88 & & 104 & 105 & 106 & 107 & 108 & 109 & 110 & 111 & 112 & 113 & 114 & 115 & 116 & 117 & 118 \\
\hline $\mathbf{F r}$ & $\mathbf{R a}$ & 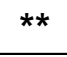 & Rf & $\mathrm{Db}$ & $\mathrm{Sg}$ & Bh & Hs & Mt & Ds & $\mathbf{R g}$ & Uub & Uut & Uuq & Uup & Uuh & Uus & Uuc \\
\hline & \multirow{2}{*}{\multicolumn{2}{|c|}{ Lanthanides }} & 57 & 58 & 59 & 60 & 61 & 62 & 63 & 64 & 65 & 66 & 67 & 68 & 69 & 70 & 71 \\
\hline & & & La & $\mathrm{Ce}$ & $\mathrm{Pr}$ & Nd & Pm & $\mathrm{Sm}$ & Eu & Gd & $\mathrm{Tb}$ & Dy & Ho & Er & Tm & Yb & Lu \\
\hline & \multicolumn{2}{|l|}{$A C$} & $\begin{array}{c}89 \\
\text { Ac }\end{array}$ & $\begin{array}{c}90 \\
\text { Th }\end{array}$ & $\begin{array}{c}91 \\
\mathbf{P a}\end{array}$ & $\begin{array}{l}92 \\
\mathbf{U}\end{array}$ & $\begin{array}{c}93 \\
\mathrm{~Np}\end{array}$ & $\begin{array}{c}94 \\
\mathbf{P u}\end{array}$ & $\begin{array}{c}95 \\
\mathrm{Am}\end{array}$ & $\begin{array}{c}96 \\
\mathrm{Cm}\end{array}$ & $\begin{array}{c}97 \\
\text { Bk }\end{array}$ & $\begin{array}{c}98 \\
\text { Cf }\end{array}$ & $\begin{array}{c}99 \\
\text { Es }\end{array}$ & $\begin{array}{l}100 \\
\text { Fm }\end{array}$ & $\begin{array}{c}101 \\
\text { Md }\end{array}$ & $\begin{array}{c}102 \\
\text { No }\end{array}$ & $\begin{array}{l}103 \\
\mathbf{L r}\end{array}$ \\
\hline
\end{tabular}

Elemental analyser

Ion chromatography after combustion

ICP-MS after acid digestion

ICP-OES after acid digestion
Oxygen bomb calorimeter

$550^{\circ} \mathrm{C}$

Mercury analyser

Rare earth element (REE)

Figure 2 - Overview of analysed physical and chemical parameters, employed measurement techniques and elements included in the group rare earth elements (REE). 
Table 1 - Overview of analysed fractions from residual and source-segregated waste and employed acid digestions methods.

\begin{tabular}{|c|c|c|c|c|c|}
\hline Material type & ID & Waste fraction & Residual & Source-segregated (SS) & Acid digestion method \\
\hline \multirow{8}{*}{ 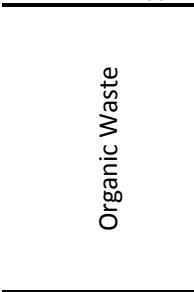 } & F1 & Animal-derived food waste & 回 & ? & \multirow{2}{*}{ EN 13656} \\
\hline & F2 & Vegetable food waste & 回 & 回 & \\
\hline & $\mathrm{Y} 1$ & Plant material & 回 & 国 & \multirow{6}{*}{ USEPA 3052} \\
\hline & Y2 & Woody plant material & 回 & ? & \\
\hline & Y3 & Humus & 回 & 回 & \\
\hline & Y4 & Animal excrements-dog & 回 & ? & \\
\hline & Y5 & Animal excrements-cat & 回 & 回 & \\
\hline & Y6 & Animal bedding & 回 & ? & \\
\hline \multirow{8}{*}{ 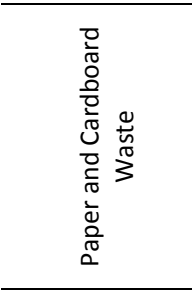 } & PC1 & Magazines and advertisement & 回 & ? & \multirow{8}{*}{ USEPA 3051} \\
\hline & $\mathrm{PC} 2$ & Newsprint & ํㅜ & ? & \\
\hline & PC3 & Office/administrative paper & 回 & 回 & \\
\hline & PC4 & Books & 回 & ? & \\
\hline & PC5 & Tissue paper & 回 & ? & \\
\hline & PC6 & Other paper & 回 & ? & \\
\hline & PC7 & Cardboard and paperboard & 回 & 回 & \\
\hline & PC8 & Paper and cardboard composites & 回 & 回 & \\
\hline \multirow{14}{*}{ 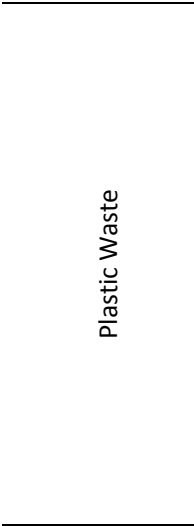 } & $\mathrm{P} 1$ & Plastic packaging-PET & 回 & 圆 & \multirow{35}{*}{ USEPA 3052} \\
\hline & P2 & Plastic packaging-HDPE & 뭉 & ? & \\
\hline & P3 & Plastic packaging-PP & 回 & ? & \\
\hline & P4 & Plastic packaging-PS & 回 & 回 & \\
\hline & P5 & Plastic packaging-expanded PS & 回 & 回 & \\
\hline & P6 & Plastic packaging-no label & 回 & ? & \\
\hline & P7 & Plastic packaging-identification code 7-19 & 回 & ? & \\
\hline & P8 & Plastic packaging-foil & 回 & 回 & \\
\hline & P9 & Plastic packaging-plastic composite & 回 & ? & \\
\hline & $\mathrm{P} 10$ & Non-packaging plastic-identification code 7-19 & 回 & ? & \\
\hline & $\mathrm{P} 11$ & Non-packaging plastic-PP & 回 & 回 & \\
\hline & $\mathrm{P} 12$ & Non-packaging plastic-PET & 回 & ? & \\
\hline & $\mathrm{P} 13$ & Non-packaging plastic-no label & 回 & ? & \\
\hline & $\mathrm{P} 14$ & Non-packaging plastic-LDPE & 回 & ? & \\
\hline \multirow{5}{*}{ 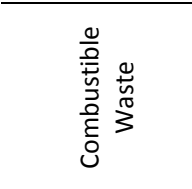 } & $\mathrm{C} 1$ & Sanitary products & 回 & 回 & \\
\hline & $\mathrm{C} 2$ & Textiles, leather, rubber & 回 & 回 & \\
\hline & C3 & Wood & 回 & ? & \\
\hline & $\mathrm{C} 4$ & Vacuum cleaner bags & 回 & 回 & \\
\hline & $\mathrm{C} 5$ & Other combustibles & 回 & ? & \\
\hline \multirow{5}{*}{ 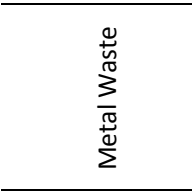 } & M1 & Metal packaging-non-ferrous & 回 & ? & \\
\hline & $\mathrm{M} 2$ & Metal packaging-ferrous & 回 & 回 & \\
\hline & M3 & Metal packaging-aluminium foil & 回 & 回 & \\
\hline & M4 & Non-packaging metal-ferrous & 回 & ? & \\
\hline & M5 & Non-packaging metal-non-ferrous & 回 & 国 & \\
\hline \multirow{10}{*}{ 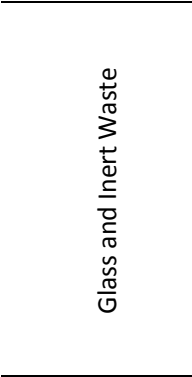 } & G1 & Glass packaging-clear & 回 & 回 & \\
\hline & $\mathrm{G} 2$ & Glass packaging-green & 回 & ? & \\
\hline & G3 & Glass packaging-brown & 回 & 回 & \\
\hline & G4 & Kitchen and table ware glass & 回 & 回 & \\
\hline & G5 & Other/special glass & 回 & ? & \\
\hline & i1 & Ceramics/porcelain & 国 & 国 & \\
\hline & i2 & Ashes & 回 & ? & \\
\hline & i3 & Cat litter & 回 & ? & \\
\hline & ¡4 & Gravel, sand, stones & 回 & ? & \\
\hline & i5 & Other non-combustibles & ? & ? & \\
\hline Total number: & & & 49 & 24 & \\
\hline
\end{tabular}




\subsection{Data analysis}

For the statistical evaluation of the measurement results, values below the detection limit were replaced with the concentration of the relevant detection limit concentrations. To support the comparison of the samples with each other, especially the samples from residual and source-segregated waste, Tukey-HSD-tests were performed on the measurement results for each element in all samples of similar material types using the software JMP (Version 11, SAS). Thus, the expression "significant(ly)" refers to resulting $p$-values smaller than 0.05 (assuming $95 \%$ confidence interval).

\section{Results and Discussion}

The results of the physico-chemical characterisation of 49 material fractions from residual waste and 24 fractions from source-segregated waste are presented and discussed in this section. To enable better navigation the investigated fractions were grouped into six material types as presented in Table 1: i) organic waste, ii) paper and cardboard waste, iii) plastic waste, iv) combustible waste, v) metal waste, and vi) glass and inert waste. Due to the extensive number of results only selected observations are presented, discussed, and compared to values from previous characterization studies on European waste. The selection was done both to present most important trends and to attempt identification of the possible origin of individual substances. The complete dataset of the physico-chemical composition including all parameters and waste fractions analysed, is provided in Appendix A.

\subsection{Organic Waste}

As no separate collection of organic waste from households was implemented in the study area, only organic fractions from residual waste were analysed. Overall eight organic fractions from residual household waste were investigated; two food waste and six gardening waste fractions (see Table 1). Table 2 presents selected parameters for all food waste (F1, F2) and four of the six analysed gardening waste fractions $(Y 1, Y 2, Y 3$, and Y6).

Table 2 - Mean values and standard deviation (based on three replicates) for selected analysed parameters in selected organic waste fractions in residual waste and value ranges found in literature (see Appendix A for full results).

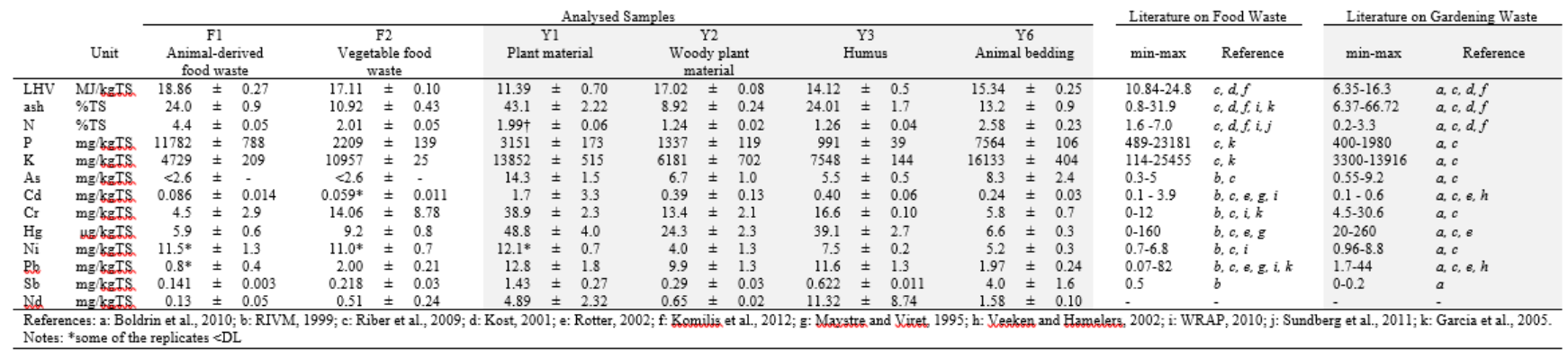

\subsubsection{Waste material properties}

The results for HHV and nutrient content differed significantly among the analysed organic samples (Table 2). Overall, animal-derived food waste presented the highest $\mathrm{N}$ content (4.37 \%TS, equivalent to 43,700 $\mathrm{mg} / \mathrm{kgTS}$ ), and a significantly higher $\mathrm{P}$ content $(11,782 \mathrm{mg} / \mathrm{kgTS})$ than all other organic samples except for animal excrements. Animal-derived food waste had significantly higher HHV and contents of $\mathrm{H}, \mathrm{N}, \mathrm{P}, \mathrm{K}, \mathrm{Ca}, \mathrm{Cl}$ than vegetable food waste, but a lower $\mathrm{K}$ content. The Ca content in animal-derived food waste $(83.8 \mathrm{mg} / \mathrm{kgTS})$ was 
about 8 times higher than in vegetable food waste, likely due to the presence of bones which consist largely of hydroxylapatite, a mineral including $\mathrm{Ca}$ and $\mathrm{P}$ (Robey and Boskey, 2009). A prevalence of bones in animalderived food waste (F1) is also supported by results for the ash content; it was double as high than found in vegetable food waste. Animal-derived food waste (F1) had also a four times higher Sr content and a three times higher Sn content than vegetable food waste; however, the reason for this remains unclear.

The highest ash content among all organic fractions was found in plant material (43\%TS). This is explained by the fact that the plant material fraction was obtained from the macro fraction of gardening waste by sorting out pieces of woody plant material, clumps of humus and bags containing dog excrements and animal bedding. Thus, a substantial amount of fine materials including soil and dust related to plants and gardening activities entered the plant material fraction (Y1). A similar ash content was reported by Boldrin and Christensen (2010) in source-segregated Danish garden waste (48.3\%TS). Plant material also showed significantly higher contents of $\mathrm{Cu}, \mathrm{Cr}, \mathrm{Fe}, \mathrm{Hg}, \mathrm{Mn}, \mathrm{Ni}$ and $\mathrm{W}$ when compared to the remaining organic waste samples analysed. Second highest concentrations of these elements were found in humus. Additionally, humus presented significantly higher concentrations of $\mathrm{Mo}$ and $\mathrm{V}$ than all other organic fractions. The Sb content in animal bedding (Y6) $(4.0 \mathrm{mg} / \mathrm{kgTS})$ was three to 13 times higher than in the other organic fractions, probably due to wood preservatives as this fraction consisted mainly of wood chips which can origin from recycled wood (Dodoo et al., 2014; Loferski, 1999). Cat excrements (Y5) presented a significantly higher Al and Cs content than the other organic material fractions, which may be due to attached cat litter, which typically consists of aluminosilicate minerals like clay or zeolite (Jha and Hayashi, 2009). The concentrations of many rare earth elements (REE) were higher in cat excrements (Y5) and humus (Y3) than in the other organic fractions.

\subsubsection{Residual vs source-segregated waste}

As in the investigated area no source-segregation of organic waste fractions was implemented, it was not possible to experimentally verify whether the high metal content was due to cross-contamination from other fractions or an intrinsic property of materials associated with gardening activities. Earlier research reported lower contents of potentially toxic metals in compost made of source-segregated organic waste and has addressed the relation to cross-contamination of organic waste with other waste constituents (Richard and Woodburry, 1992; Van Roosmalen et al., 1987). However, the concentrations of $\mathrm{As}, \mathrm{Cd}, \mathrm{Cr}$, $\mathrm{Ni}$ and $\mathrm{Sb}$ in the plant material fraction in this investigation were only slightly higher than reported in previous investigations on source-segregated gardening waste fractions (Boldrin and Christensen, 2010). The analysed Pb concentrations in all analysed organic waste fractions were comparable to the lower end of the concentration intervals reported in literature for food waste and gardening waste. The concentrations of $\mathrm{P}, \mathrm{K}$, and $\mathrm{Sb}$ in animal bedding (Y6) exceeded the literature value ranges for gardening waste and were similar to animal excrements (Y4 and Y5).

\subsubsection{Key aspects for the waste material fractioning}

As the presented results have shown, animal-derived food waste and animal excrements and bedding are concentrated sources for nutrients and determination of their share in organic waste flows is thus crucial to accurately estimate the nutrient potential of organic waste. However, sorting and quantification of animal excrements and animal bedding might be challenging if they are not bagged separately as it was the case in this sorting campaign on residual household waste. Furthermore, the distinction between animal-derived food waste and vegetable food waste is important as the interest in environmental savings from food waste prevention increases and the emissions related to production of animal-derived and vegetable-derived food products differ substantially (Reijnders and Soret, 2003). However, to fully support the development of concrete measures for food waste prevention, the material fractioning would need to consider even more 
detailed fractions to reflect the consumers' disposal behaviour, as discussed in detail by Lebersorger and Schneider (2011).

\subsection{Paper and Cardboard Waste}

The investigated paper and cardboard fractions were sampled based on waste flows (source-segregated and residual) and function (e.g. newsprint, tissue paper, etc.) (see Table 1 for details). Table 3 presents selected parameters for six paper and cardboard fractions from residual waste.

Table 3 - Mean values and standard deviation (based on three replicates) for selected analysed parameters in selected paper and cardboard waste fractions in residual waste and value ranges found in literature (see Appendix A for full results).

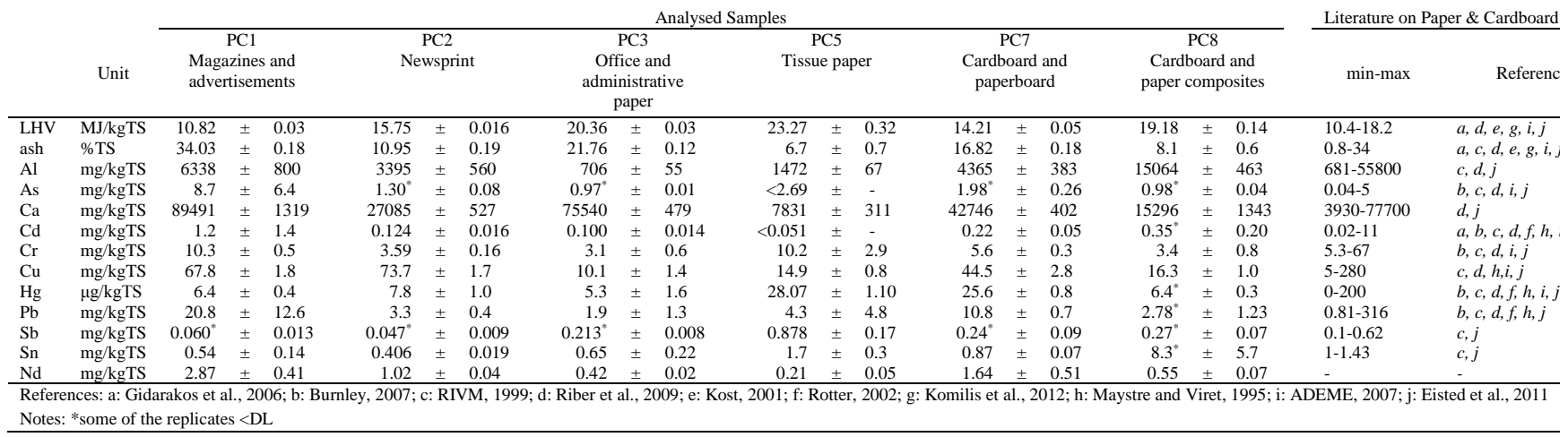

\subsubsection{Waste material properties}

Considerable differences among the paper fractions were found for many analysed parameters in both residual and source-segregated waste flows (Table 3). Tissue paper and cardboard and paper composites presented substantially different properties, i.e. higher HHV and lower ash contents than the other paper samples. Cardboard and paper composites (PC8) had the overall highest $\mathrm{C}, \mathrm{H}$ and $\mathrm{Al}$ content, which reflects very well the materials included in this fraction (i.e. laminates can include plastic and aluminium layers, which is expected to increases the HHV, C, H, Al content relative to paper-only products). Tissue paper (PC5) from residual waste had overall highest contents of nutrients and halogens ( $\mathrm{N}, \mathrm{S}, \mathrm{Ca}, \mathrm{K}, \mathrm{Na}, \mathrm{P}, \mathrm{Cl}$ and $\mathrm{F}$ ), as well as $\mathrm{Si}$ and Ti, which most likely resulted from absorbed food scraps and dust. The highest ash contents (about $30 \%$ TS) were found in magazines and advertisement (PC1), and books (PC4) from both residual and source-segregated waste flows. This was associated with higher Ca contents suggesting a high abundance of calcium carbonate fillers in these fractions (Auhorn, 2012). Mg and Sr concentrations appeared to follow the same pattern. Also, the concentrations of metals and trace elements differed considerably among the different paper fractions. The contents of $\mathrm{Cr}$ and $\mathrm{Pb}$ were consistently lower in newsprints (PC2), office paper (PC3) and books (PC4) than in other fractions, which might be due to different quantity and types of inks used (Pivnenko et al., 2015a). Also $\mathrm{Cu}$ in office paper (PC3) and books (PC4), and Mn in office paper (PC3) only, were present at considerably lower concentration levels than observed in the other paper and cardboard fractions. The Hg content was higher in the fractions tissue paper (PC5), other paper (PC6), and cardboard and paperboard (PC7) than observed in the other fractions. The highest concentrations of REE were found in magazines and advertisement (PC1); this fraction was also associated with high filler contents (i.e. higher $\mathrm{Ca}$ and ash content). The REE could thus be related to the used filler materials such as mineral raw materials (Auhorn, 2012). 


\subsubsection{Residual vs source-segregated waste}

The HHV of tissue paper (PC5), and cardboard and paper composites (PC8) was considerably higher in the samples from residual waste than in the samples from source-segregated waste. Considerably higher contents of $\mathrm{K}, \mathrm{Na}, \mathrm{Nb}, \mathrm{P}, \mathrm{S}, \mathrm{Si}$, and Ti were found in the tissue paper (PC5) in residual waste than in the same fraction in source-segregated waste. $\mathrm{C}$ and $\mathrm{H}$ content of cardboard and paper composite (PC8) in residuals waste was considerably higher and its ash content lower than in the source-segregated waste. According to the sorting guidelines in the sampling area both fractions (PC5 and PC8) were not supposed to enter the sourcesegregated waste flow and the mistakenly discarded items were cleaner and of different types than found in the complementary fraction in residual waste (i.e. a higher share of juice and milk boxes than yoghurt packaging, where the latter are more likely to contain food residue due to the high viscosity of yoghurt). Possibly these fractions were perceived as cleaner by the person performing the source-segregation and therefore considered as recyclable paper products. Visually clean, however, does not equal less problematic; the concentrations of several metals and elements with toxic relevance (e.g. $\mathrm{Ba}, \mathrm{Cu}, \mathrm{Ga}, \mathrm{Hg}, \mathrm{Pb}$ and $\mathrm{Zn}$ ) were higher in the cardboard and paper composites (PC8) disposed of in source-segregated waste than in the same fraction disposed of in the residual waste. Surprisingly the $\mathrm{Hg}$ concentration in paper and cardboard composite (PC8) in source-segregated waste was the second highest among all analysed waste fractions; only vacuum cleaner bags (C4) from residual waste had higher $\mathrm{Hg}$ content. Conversely, in the sample magazines and advertisements (PC1) from residual waste higher levels of As, Cd and Tl were found than in the corresponding sample from source-segregated waste. The ash content of magazines and advertisements (PC1) and cardboard and paperboard (PC7) from residual waste was $3 \%$ and $2 \%$ higher than in the respective fractions from sourcesegregated waste, whereas for office paper (PC3) the opposite was found. Whether these differences result from cross-contamination, different disposal patterns or natural variability is not clear at this point and could only be specified by repeated sampling and thorough documentation of disposed items.

\subsubsection{Key aspects for the waste material fractioning}

Overall these results show that higher concentrations of metals in paper and cardboard waste are not necessarily a result of cross-contamination from other waste materials due to mixed waste collection, but may be intrinsic properties of certain paper and cardboard products (e.g. inks and fillers). As described above, some fractions in source-segregated waste in fact presented higher contents of metals and potentially toxic elements than the complementary fractions in the residual waste. The example of tissue paper (PC5) and paper and cardboard composites (PC8), which were mistakenly disposed of in source-segregated waste, showed that the properties of misplaced materials in the source-segregated waste flow may differ significantly from the ones in residual waste although they were accounted as the same material fraction. Items occurring in very low quantities may become of higher importance to ensure good quality of paper recyclables as it was discussed by Pivnenko et al. (2015) for the case of receipts containing Bisphenol A.. Thus distinguishing paper waste fractions by product type is very important also because some paper products, e.g. tissue paper are typically not recyclable (Baeyens et al., 2010a).

\subsection{Plastic Waste}

The investigated plastic fractions were sampled based on waste flows (source-segregated or residual), function (packaging or non-packaging), and polymer resin (PET, PE, PP, PS, others) (see Table 1 for details). Overall 13 fractions from residual and seven fractions from source-segregated waste were analysed (not all defined fractions were present in the source-segregated waste). Table 4 presents selected parameters for six plastic packaging fractions in residual waste. 
Table 4 - Mean values and standard deviation (based on three replicates) for selected analysed parameters in selected plastic waste fractions in residual waste and value ranges found in literature (see Appendix A for full results).

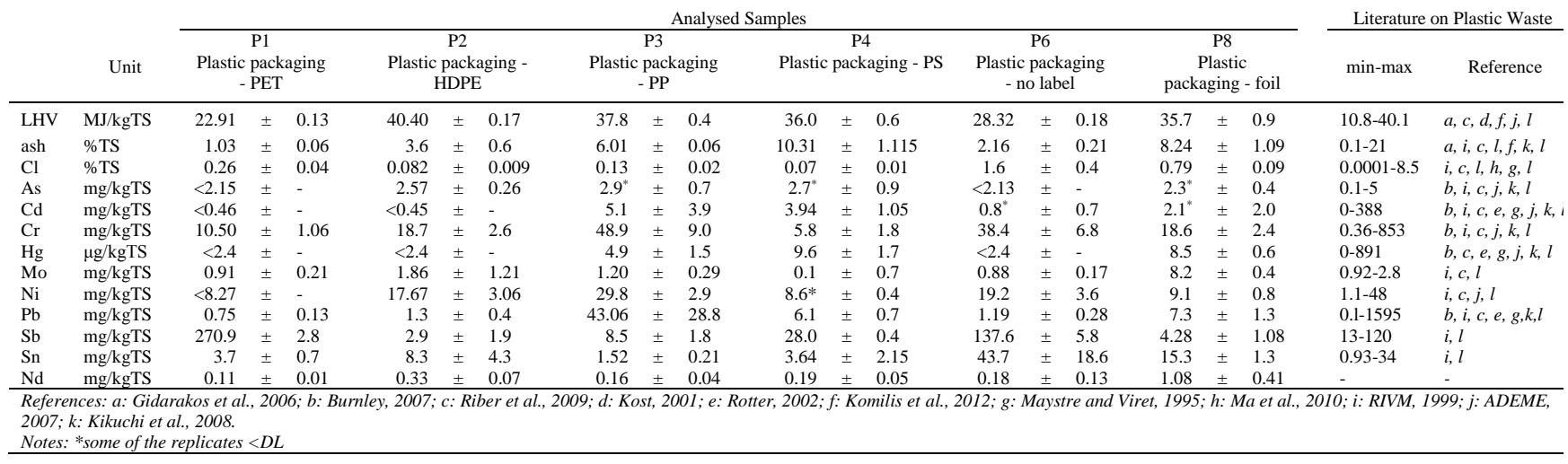

\subsubsection{Waste material properties}

For many parameters significant differences between the analysed plastic fractions were found. The LHV and ash content differed substantially between polymer resins, but the results were still within the range reported in literature (Table 4). In particular, the LHV, C and H content of PET (polyethylene terephthalate) packaging (P1) was considerably lower than found in the other polymer resins. Sb concentrations in PET packaging were about $250 \mathrm{mg} / \mathrm{kgTS}$, thus significantly higher than in all other samples (Figure 3). Sb has a high toxicity potential, is widely used in PET manufacturing as a catalyst, and the measured Sb concentrations were similar to the ones found by Westerhoff et al. (2008) in PET drinking water bottles. The high Sb content in PET packaging is thus not a waste-specific impurity but a potential problem of the product itself. Tests revealed that only a small fraction of the total Sb content is leachable into water (Westerhoff et al., 2008) but whether the release rate could be altered by recycling and remanufacturing processes and possibly increase the risks for human health and environment has not been addressed so far. As expected the highest Al content was found in plastic composite packaging (P9; i.e. laminates of thin plastic and metal layers; e.g. potato chips packaging) along with higher $\mathrm{V}, \mathrm{Sn}$ and $\mathrm{Zr}$ contents than measured in the other plastic fractions. About a quarter of all the plastic waste collected was not labelled with any polymer resin (P6, P13). Non-labelled packaging (P6) included mainly rather flexible material often with glued foils as covers, and was typically used for packaging of cold cuts and sliced cheese. Non-labelled packaging (P6) and non-packaging plastic fractions (P13), and metal-plastic laminates (P9) presented significantly higher $\mathrm{Cl}$ contents (1.6-3.6 \%TS) than the other plastic fractions (0.004$0.261 \% \mathrm{TS}$ ), suggesting an abundance of PVC (polyvinylchloride), which includes $\mathrm{Cl}$ atoms in its molecular structure. Ma et al. (2010) reported a chlorine content of 6 \%TS in PVC-rich plastic waste but pure PVC has been reported to contain around 50 \% chlorine (Summers, 1997). Our interpretation on the presence of PVC in non-labelled plastic fractions is supported by the fact that also significantly higher Sn contents were found in these fractions and organotin is used as a stabilizer in PVC (Wypych, 2008). Non-packaging plastic without polymer resin label (P13) presented significantly higher contents of $\mathrm{Ba}, \mathrm{Cu}, \mathrm{Cr}, \mathrm{Fe}, \mathrm{Ga}, \mathrm{Hg}, \mathrm{Mn}, \mathrm{Ni}, \mathrm{Pb}, \mathrm{Sr}$ and $\mathrm{Zn}$ than found in the other plastic waste samples. 


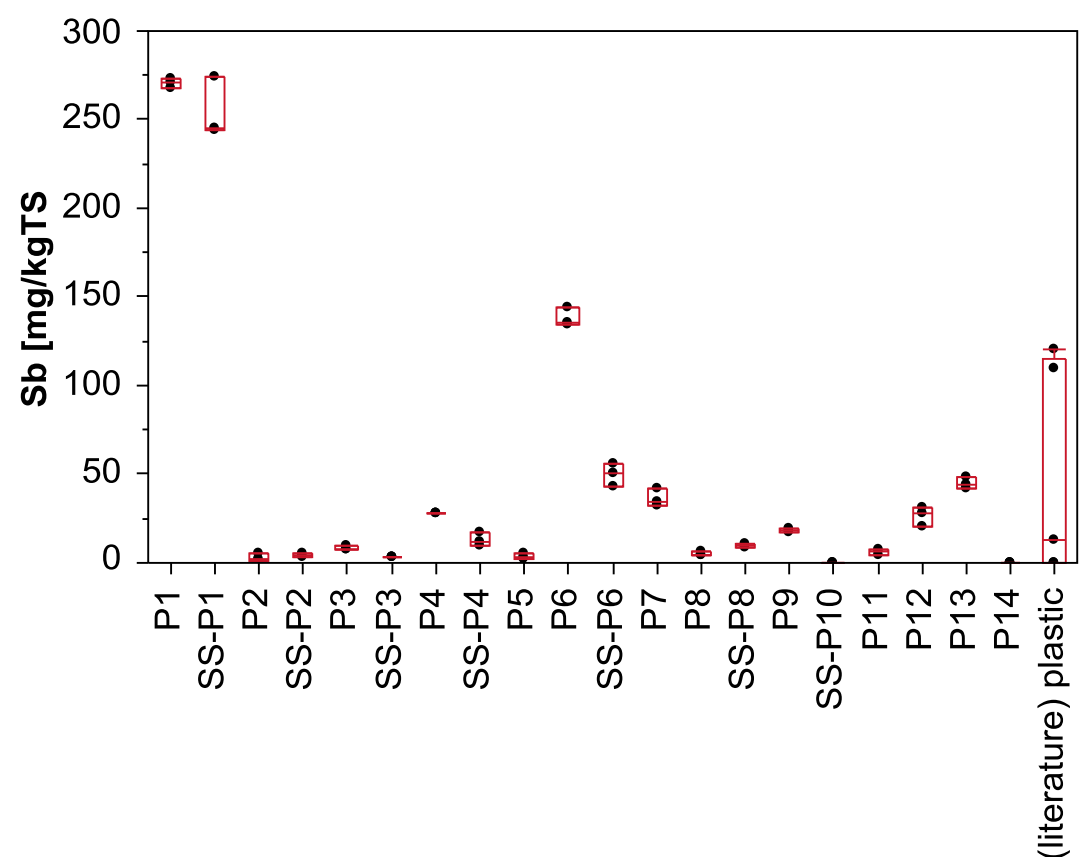

Figure 3 - Sb content in the investigated plastic fractions; SS: source-segregated.

\subsubsection{Residual vs source-segregated waste}

Significant differences between residual and source-segregated plastic waste fraction were found for many parameters. The LHV was significantly higher in the source-segregated plastic packaging fractions made of PP (polypropylene) (P3), PS (polystyrene) (P4) and non-labelled polymer resin (P6), than in the corresponding residual fractions. Higher levels of nutrients and salts were expected in plastic from residual waste due to food scraps, which should be rinsed off the plastic for source-segregated collection. In fact, the P content of nearly all samples from residual waste was significantly higher than in the samples from source-segregated plastic waste (the only exception of this observation was PET packaging, which mainly consisted of beverage bottles). However, no significant differences of $\mathrm{N}$ contents between residual and source-segregated fractions were apparent and for $\mathrm{S}, \mathrm{Na}, \mathrm{Cl}$, and $\mathrm{K}$ differences were found only for few fractions. In particular, a significant difference of the $S$ content between source-segregated and residual waste flow was found only for HDPE (high density polyethylene) packaging (P2). As this polymer resin was mostly used for packaging of cosmetic and cleaning products, the higher $\mathrm{S}$ content could origin from residues of these products e.g., from sodium lauryl sulfate, which is commonly used in cosmetic products (Robinson et al., 2010). Hg concentrations of PS and PP packaging (P3 and $\mathrm{P} 4$ ) in residual waste were significantly higher than the corresponding samples from sourcesegregated waste. However, no significant difference between residual and source-segregated samples was found for the elements $\mathrm{Ba}, \mathrm{Co}, \mathrm{Cr}, \mathrm{Cu}, \mathrm{Fe}, \mathrm{Mn}, \mathrm{Ni}, \mathrm{Pb}$ and $\mathrm{Zn}$.

\subsubsection{Key aspects for the waste material fractioning}

The results emphasize the importance of distinguishing plastic fractions by application (e.g. packaging vs. nonpackaging) and polymer resin as (i) physico-chemical properties may be intrinsic properties of polymer resin (e.g. Sb in PET packaging, and $\mathrm{Cl}$ and $\mathrm{Sn}$ in PVC) and (ii) the environmental savings of plastic recycling depend crucially on the recycled polymer resin and downstream substitution (Arena and Di Gregorio, 2014; Astrup et 
al., 2009). Based on the results for potentially toxic metals, the distinction between residual and sourcesegregated plastic waste flows appears to be of little importance.

\subsection{Combustible Waste}

The investigated combustible waste samples comprised five material fractions from residual waste and one material fraction from source-segregated waste (see Table 1 for details). Table 5 presents selected parameters for all analysed combustible waste fractions.

Table 5 - Mean values and standard deviation (based on three replicates) for selected analysed parameters in all combustible waste fractions from residual and source-segregated (SS) waste, and value ranges found in literature (see Appendix A for full results).

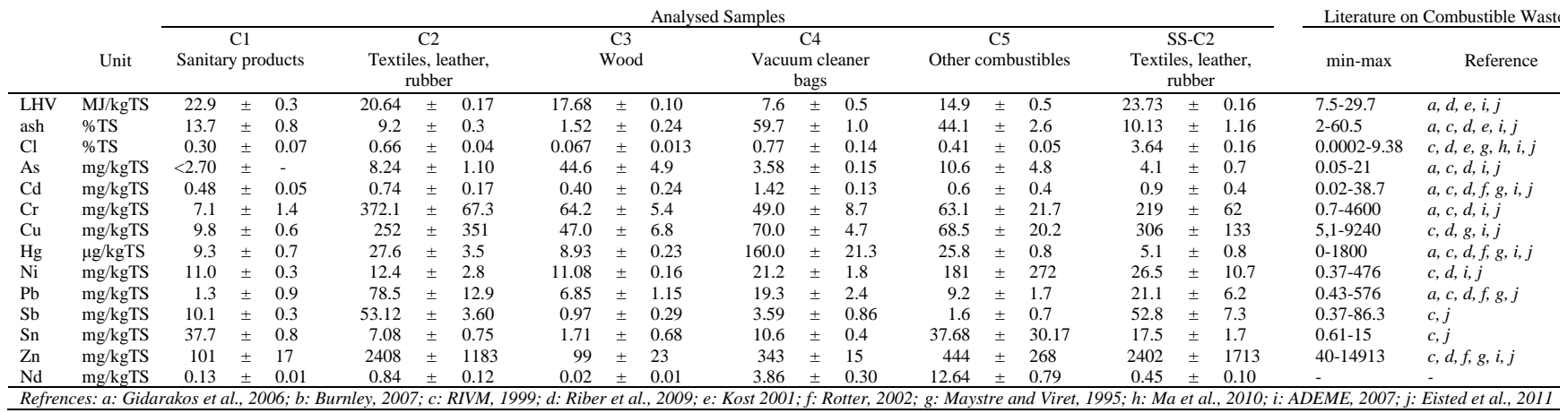

\subsubsection{Waste material properties}

Significant differences in LHV, ash content, and $\mathrm{C}$ and $\mathrm{H}$ content were observed among the analysed combustible fractions. The lowest LHV (7.6 MJ/kgTS), C content (23.2\%TS), H content (3.2\%TS), and highest ash content (59.7\%TS) were found in vacuum cleaner bags (C4) and the results were similar to values reported by Riber et al. (2009) and Kost (2001). Also the fraction other combustibles (C5) presented significantly lower LHV, C and H content, and a significantly a higher ash content than sanitary products (C1), wood (C3), and textiles, rubber and leather (C2). Additionally, vacuum cleaner bags (C4) and other combustibles (C5) presented the highest concentrations of many macro and trace elements among all combustible waste fractions, in particular Al, Ca, Mg, P, and Si as well as Cs, Ge, Mn, Mo, REE, Ta, U, V. This suggests that these trace elements are accumulated in small inorganic particles, i.e. dust. The highest As concentration was found in wood (C3; $44.6 \mathrm{mg} / \mathrm{kgTS}$ ) and originated likely from wood preservatives (Loferski, 1999). The overall highest $\mathrm{Hg}$ concentration was found in vacuum cleaner bags (C4; $160 \mu \mathrm{g} / \mathrm{kgTS}$ ). Textiles, leather and rubber (C2) showed the highest concentrations of $\mathrm{Cu}, \mathrm{Cr}, \mathrm{Sb}$, and $\mathrm{Zn}$ among the combustible fractions. The Sn concentration in sanitary products (C1; $37.7 \mathrm{mg} / \mathrm{kgTS}$ ) was similar to the one in other combustibles $(\mathrm{C} 5 ; 37.7 \mathrm{mg} / \mathrm{kgTS})$ and significantly higher than in the remaining combustible waste samples, which might be due to application of tin oxide either as white masking material for sanitary products (Karapasha 1995) or via diaper rash cream (typically containing tin oxide).

\subsubsection{Residual versus source-segregated waste}

The materials considered as combustible waste in this investigation (e.g. sanitary products, and leather, rubber and textiles) were not supposed to enter the source-segregated waste flow. Nevertheless, relatively small amounts of materials fitting the fraction textiles, rubber, and leather (C2) were found in the source-segregated waste flow. Consequently a comparison between source-segregated and residual waste was performed only 
for the fractions textiles, rubber and leather (C2). The concentrations of $\mathrm{S}, \mathrm{Mg}, \mathrm{P}, \mathrm{As}, \mathrm{Cr}, \mathrm{Pb}$, Th, and several REE were higher in the sample from residual waste, while the LHV and the contents of $\mathrm{C}, \mathrm{N}, \mathrm{Br}, \mathrm{Cl}, \mathrm{Ba}, \mathrm{Co}, \mathrm{Ga}, \mathrm{Nb}$, $\mathrm{Ta}, \mathrm{W}, \mathrm{Sr}$ and Ti were higher in the source-segregated waste. However, it is difficult to conclude whether these differences were due to cross-contamination or were resulting from the intrinsic differences of the disposed of textile, rubber and leather products. For example, the higher $\mathrm{Cl}$ and $\mathrm{N}$ content in the sample from sourcesegregated waste might possibly be due to a larger abundance of PVC (molecule includes $\mathrm{Cl}$ atoms) and polyamide (molecule includes $\mathrm{N}$ atoms). Similarly, an association of trace metals with different products cannot be excluded.

\subsubsection{Key aspects for the waste material fractioning}

Combustible fractions generally represent material fractions intended for waste incineration. Differences in LHV are thus of crucial importance to properly estimate the energy content of the combustible waste fraction. However, for few materials recycling options may exist (e.g. for wood and textiles). Typically, these fractions represent materials that are difficult for households to sort further into recyclable materials. Also during waste characterization activities a more detailed fractioning of combustible waste materials is not feasible without disintegrating the discarded products in the waste. For example, clear distinction of textiles, rubber and leather was difficult as many items were a mixture of all materials (e.g. shoes, bags, carpets). However, a distinction of combustible waste into sanitary products, vacuum cleaner bags, wood, and textile, rubber and leather, from other and small combustible items was possible and appears useful as their physico-chemical properties differ substantially from other combustible fractions and because source-segregation schemes for these materials may exist.

\subsection{Metal Waste}

The investigated metal waste fractions were sampled based on waste flows (source-segregated or residual), function (packaging or non-packaging), and were further distinguished into ferrous, non-ferrous, and aluminium foil. Table 6 presents selected parameters for five of the six analysed metal waste fractions.

Table 6 - Mean values and standard deviation (based on three replicates) for selected analysed parameters in selected metal waste fractions in residual and source-segregated (SS) waste, and value ranges found in literature (see Appendix A for full results).

\begin{tabular}{|c|c|c|c|c|c|c|c|c|c|c|c|c|c|c|c|c|c|c|c|c|c|}
\hline \multirow[b]{3}{*}{$\mathrm{LHV}_{\dagger}^{\dagger}$} & \multirow{3}{*}{$\begin{array}{c}\text { Unit } \\
\mathrm{MJ} / \mathrm{kgTS}\end{array}$} & \multicolumn{18}{|c|}{ Analysed Samples } & \multicolumn{2}{|c|}{ Literature on Combustib } \\
\hline & & \multicolumn{3}{|c|}{$\begin{array}{c}\text { M1 } \\
\text { Metal packaging } \\
\text { - non-ferrous }\end{array}$} & \multicolumn{3}{|c|}{$\begin{array}{c}\text { M2 } \\
\text { Metal packaging } \\
\text { - ferrous } \\
\end{array}$} & \multicolumn{3}{|c|}{$\begin{array}{c}\text { M3 } \\
\text { Metal packaging } \\
\text { - aluminium foil } \\
\end{array}$} & \multicolumn{3}{|c|}{$\begin{array}{c}\text { M4 } \\
\text { Non-packaging metal } \\
\text { - ferrous }\end{array}$} & \multicolumn{3}{|c|}{$\begin{array}{c}\text { M5 } \\
\text { Non-packaging } \\
\text { metal - non-ferrous }\end{array}$} & \multicolumn{3}{|c|}{$\begin{array}{c}\text { SS-M1 } \\
\text { Metal packaging } \\
\text { - non-ferrous }\end{array}$} & \multirow{2}{*}{$\begin{array}{l}\min -\max \\
-0.1-10.73\end{array}$} & \multirow{2}{*}{$\begin{array}{l}\text { Reference } \\
c, f, g\end{array}$} \\
\hline & & 4.07 & \pm & 0.28 & 1.19 & \pm & 0.99 & 4.70 & \pm & 0.13 & 8.80 & \pm & 0.7 & 22.3 & \pm & 2.8 & 0.63 & \pm & 0.09 & & \\
\hline ash & $\% \mathrm{TS}$ & 89.4 & \pm & 0.5 & 99.9 & \pm & 1.1 & 81.4 & \pm & 0.8 & n.a. & \pm & - & 36.9 & \pm & 2.9 & 99.3 & \pm & 0.3 & $76.1-100$ & $c, f$ \\
\hline $\mathrm{Al}$ & $\% \mathrm{TS}$ & 13.0 & \pm & 3.4 & 2.29 & \pm & 0.15 & 12.88 & \pm & 3.14 & 5.91 & \pm & 0.20 & 9.7 & \pm & 0.6 & 32.26 & \pm & 2.7 & $0.086-86.1$ & $b, c, g$ \\
\hline $\mathrm{Fe}$ & $\% \mathrm{TS}$ & 0.35 & \pm & 0.21 & 82.2 & \pm & 2.4 & 1.7 & \pm & 1.7 & 51.92 & \pm & 1.24 & 0.38 & \pm & 0.16 & 0.40 & \pm & 0.09 & $0.015-98$ & $b, c, g$ \\
\hline As & $\mathrm{mg} / \mathrm{kgTS}$ & $1.79^{*}$ & \pm & 0.17 & 20.2 & \pm & 1.6 & 2.9 & \pm & 0.6 & 30.6 & \pm & 1.0 & 5.3 & \pm & 2.5 & $<1.73$ & \pm & - & $2-539$ & $a, b, c, f, g$ \\
\hline $\mathrm{Cd}$ & $\mathrm{mg} / \mathrm{kgTS}$ & 0.20 & \pm & 0.02 & $<0.094$ & \pm & - & $<0.094$ & \pm & - & 2.41 & \pm & 0.29 & 1.0 & \pm & 0.4 & 0.28 & \pm & 0.08 & $0.1-53$ & $a, b, c, d, c$ \\
\hline Co & $\mathrm{mg} / \mathrm{kgTS}$ & 2.68 & \pm & 0.17 & 24.1 & \pm & 1.5 & 2.4 & \pm & 0.3 & 39.1 & \pm & 2.4 & 3.2 & \pm & 0.5 & 2.79 & \pm & 0.12 & $8-50$ & $b, g$ \\
\hline $\mathrm{Cr}$ & $\mathrm{mg} / \mathrm{kgTS}$ & 167.4 & \pm & 36.4 & 289.3 & \pm & 9.7 & 41.4 & \pm & 22.8 & 1399 & \pm & 418 & 458 & \pm & 270 & 128.9 & \pm & 6.8 & $9.4-172$ & $a, c, f, g$ \\
\hline $\mathrm{Hg}$ & $\mu \mathrm{g} / \mathrm{kgTS}$ & 2.67 & \pm & 0.25 & 2.77 & \pm & 0.23 & 12.27 & \pm & 1.6 & n.a. & \pm & - & 6.6 & \pm & 0.3 & $<2.4$ & \pm & - & $0-200$ & $b, c, d, e, f$ \\
\hline $\mathrm{Ni}$ & $\mathrm{mg} / \mathrm{kgTS}$ & 63.9 & \pm & 4.7 & 271 & \pm & 19 & 43.6 & \pm & 11.7 & 1808 & \pm & 248 & 687 & \pm & 217 & 57.43 & \pm & 3.10 & $8-387$ & $b, c, f, g$ \\
\hline $\mathrm{Mn}$ & $\mathrm{mg} / \mathrm{kgTS}$ & 5328 & \pm & 103 & 2411 & \pm & 75 & 1370 & \pm & 63 & 3893 & \pm & 79 & 774 & \pm & 103 & 7600 & \pm & 148 & $240-5140$ & $b, c, g$ \\
\hline $\mathrm{Sb}$ & $\mathrm{mg} / \mathrm{kgTS}$ & 0.76 & \pm & 0.13 & 5.4 & \pm & 0.6 & 1.01 & \pm & 0.11 & 28.32 & \pm & 2.08 & 23.61 & \pm & 11.22 & 0.96 & \pm & 0.23 & $0.5-2000$ & $b, d, g$ \\
\hline Sn & $\mathrm{mg} / \mathrm{kgTS}$ & 23.88 & \pm & 1.16 & 2759 & \pm & 31 & 15.3 & \pm & 2.2 & 770 & \pm & 356 & 76.4 & \pm & 45.9 & 22.5 & \pm & 1.0 & $67-3710$ & $b, g$ \\
\hline $\mathrm{Zn}$ & $\mathrm{mg} / \mathrm{kgTS}$ & 261.3 & \pm & 5.4 & 178.0 & \pm & 13.5 & 136.2 & \pm & 10.9 & 23540 & \pm & 7024 & 13631 & \pm & 9746 & 387 & \pm & 52 & $7.3-51200$ & $b, c, d, e, f$ \\
\hline $\mathrm{Nd}$ & $\mathrm{mg} / \mathrm{kgTS}$ & 0.46 & \pm & 0.10 & 0.13 & \pm & 0.03 & 0.70 & \pm & 0.09 & 1.71 & \pm & 0.29 & 0.31 & \pm & 0.05 & 0.14 & \pm & 0.07 & - & - \\
\hline
\end{tabular}




\subsubsection{Waste material properties}

As described in the material and methods sections the LHV of the analysed metal samples was estimated based on the contents of $\mathrm{C}, \mathrm{H}, \mathrm{N}, \mathrm{O}$, and $\mathrm{S}$ and thus represents the energy content related to combustible materials attached to the metal items, such as paper labels, plastic linings, and food residues. The direct measurement of the HHV in pulverized metal samples following the standard procedure leads to misleading results, as the reaction of metals with an oxygen-enriched atmosphere releases large amounts of heat (Grosse and Conway, 1958). This energy is, however, of no relevance for the typical waste incineration process, which uses air for the combustion. The amount of organic matter in the non-packaging metal fractions (M4, M5) was substantially higher than in metal packaging fractions (M1, M2, M3) as indicated by a comparatively high LHV (8.8 and $22.3 \mathrm{MJ} / \mathrm{kgTS}$ ) and low ash content (36.9\%TS) (Table 4). To put this in an overall perspective, other combustibles (C5) had a lower LHV (14.9 MJ/kgTS) and higher ash content (59.7\%TS) than non-packaging metal fractions. This emphasizes the problem in generalising even basic properties of macro-fractions such as metals and combustibles, as the value range of physico-chemical properties may overlap for certain sub-fractions. The ash content of ferrous metal packaging from source-segregated waste exceeded $100 \%$ TS (104 \%TS), indicating a slight increase in the sample mass during the trial, which could be due to a partial oxidation of the metal on the particles' surfaces in absence of organic matter. Significant differences between the analysed metal samples were also found with respect to many potentially toxic metals and trace elements. Ferrous metal packaging (M2) was associated with higher Sn contents and all ferrous metal fractions (M2, M4) presented higher concentrations of As, Co, and Ge than the non-ferrous fractions (M1, M3, M5). Conversely, the nonferrous fractions (M1, M3, M5) had higher contents of $\mathrm{Ga}, \mathrm{Mg}, \mathrm{Mn}, \mathrm{Na}$, $\mathrm{Hf}$ and $\mathrm{Zr}$ than the ferrous metal fractions (M2, M4). These observations are in agreement with reports that ferrous metal packaging is often made of tin-coated steel and aluminium cans of aluminium sheet alloyed with $\mathrm{Mn}$ and $\mathrm{Mg}$ (ArcelorMittal, 2015; Baeyens et al., 2010a, 2010b). Aluminium foil (M3) had a significantly higher $\mathrm{Hg}$ concentration than the other metal fractions. The highest concentrations of $\mathrm{Cd}, \mathrm{Cr}, \mathrm{Ni}, \mathrm{Pb}, \mathrm{Sb}$ and $\mathrm{Zn}$ were found in the non-packaging fractions (ferrous and non-ferrous) suggesting that these fractions are a concentrated source of many potentially toxic metals.

\subsubsection{Residual versus source-segregated waste}

Only metal packaging fractions were found in the source-segregated waste flow and thus a comparison of residual and source-segregated waste was only possible for metal packaging fractions (M1, M2). The contents of ash and Al in non-ferrous metal packaging (M1) from source-segregated waste were significantly higher than in the same material fraction from residual waste. This indicates higher amounts of organic material in the residual waste samples which could be due to cross-contamination with e.g. food scraps. The $\mathrm{C}$ content of the samples showed, however, no significant difference. The samples from residual waste had significantly higher concentrations of several potentially toxic metals and trace elements than the samples from source-segregated waste. In particular this was the case for $\mathrm{Nb}, \mathrm{Ti}, \mathrm{U}, \mathrm{Ce}$, La and $\mathrm{Pr}$ in non-ferrous metal packaging (M1), and for As, Co, Sn and $\mathrm{Sr}$ in ferrous metal packaging (M2). Furthermore, all measurements of $\mathrm{P}$ and $\mathrm{Hg}$ in sourcesegregated metal fractions were below the detection limit, whereas $\mathrm{P}$ and $\mathrm{Hg}$ contents in the residual samples were fully quantified. These differences could possibly be due to cross-contamination from organic and other waste materials but variation in the discarded product types could be a cause as well.

\subsubsection{Key aspects for the waste material fractioning}

The results of the physico-chemical characterisation of the metal samples emphasize the need to distinguish metal waste by ferrous and non-ferrous materials, and by packaging and non-packaging applications. Furthermore, fractioning metal waste by metal type e.g. ferrous (steel) and non-ferrous (e.g. aluminium, 
copper, zinc, lead) metal is of crucial importance to accurately account emissions of metal recycling as it involves different metallurgical processing (Baeyens et al., 2010a, 2010b; Dubreuil et al., 2010; Worell and Reuter, 2014). Magnetic separation is a basic operation in sorting facilities to sort metal scrap for recycling and magnets can also be easily used during manual waste sorting. While ferritic and martensitic steel are magnetic, austenitic steel cannot be sorted out with a magnet and will remain with the non-ferrous metal fraction. A further distinction of mixed non-ferrous metals and austenitic steel can be achieved on an industrial scale by eddy-current separation but during waste characterisation campaigns, which rely on manual sorting this is more difficult to implement, however, desirable.

\subsection{Glass and Inert Waste}

The investigated glass and inert waste fractions were sampled based on waste streams (source-segregated or residual). Glass waste fractions were also distinguished by function (packaging or non-packaging) and colour (clear, brown, green). For glass waste five fractions from residual waste and 4 fractions from source-segregated waste, and for inert waste four fractions from residual and two fractions from source-segregated waste were analysed. Table 7 presents selected parameters for four glass and two inert waste samples from the residual waste flow.

Table 7 - Mean values and standard deviation (based on three replicates) for selected analysed parameters in selected glass and inert waste fractions in residual waste and value ranges found in literature (see Appendix A for full results).

\begin{tabular}{|c|c|c|c|c|c|c|c|c|c|c|c|c|c|c|c|c|c|c|c|c|c|c|}
\hline \multirow[b]{3}{*}{ LHV } & \multirow{3}{*}{$\begin{array}{l}\text { Unit } \\
\mathrm{MJ} / \mathrm{kgTS}\end{array}$} & \multicolumn{18}{|c|}{ Analysed Samples } & \multicolumn{2}{|c|}{ Literature on Glass Waste } & \multirow{3}{*}{$\begin{array}{l}\text { Literatur } \\
\min -\max \\
0-10.5\end{array}$} \\
\hline & & \multicolumn{3}{|c|}{$\begin{array}{c}\text { G1 } \\
\begin{array}{l}\text { Glass packaging - } \\
\text { clear }\end{array} \\
\end{array}$} & \multicolumn{3}{|c|}{$\begin{array}{c}\text { G2 } \\
\text { Glass packaging - } \\
\text { green } \\
\end{array}$} & \multicolumn{3}{|c|}{$\begin{array}{c}\text { G3 } \\
\text { Glass packaging - } \\
\text { brown } \\
\end{array}$} & \multicolumn{3}{|c|}{$\begin{array}{c}\mathrm{G} 4 \\
\text { Glass - kitchen and } \\
\text { tableware glass }\end{array}$} & \multicolumn{3}{|c|}{$\begin{array}{c}\text { il } \\
\text { Ceramic }\end{array}$} & \multicolumn{3}{|c|}{$\begin{array}{c}\text { i3 } \\
\text { Cat litter }\end{array}$} & \multirow{3}{*}{$\begin{array}{l}\text { min-max } \\
0-0.72 \\
98.8-100\end{array}$} & \multirow{2}{*}{$\begin{array}{l}\text { Reference } \\
c, f g\end{array}$} & \\
\hline & & 0.57 & \pm & 0.09 & $<0.175$ & \pm & - & 0.45 & \pm & 0.10 & $<0.175$ & \pm & - & $<0.148$ & \pm & - & $<-0.030$ & \pm & - & & & \\
\hline ash & $\% \mathrm{TS}$ & 97.13 & \pm & 0.27 & 99.13 & \pm & 0.05 & 96.1 & \pm & 0.5 & 99.77 & \pm & 0.08 & 97.2 & \pm & 0.1 & 99.2 & \pm & 0.9 & & $b, c, f, g$ & $43.9-100$ \\
\hline $\mathrm{C}$ & $\% \mathrm{TS}$ & 1.56 & \pm & 0.07 & 0.50 & \pm & 0.03 & 1.6 & \pm & 0.3 & 0.25 & \pm & 0.14 & 0.74 & \pm & 0.01 & 0.62 & \pm & 0.01 & $0-1.2$ & $c, f, g$ & $0-30$ \\
\hline $\mathrm{Al}$ & $\mathrm{mg} / \mathrm{kgTS}$ & 6681 & \pm & 169 & 8515 & \pm & 198 & 9925 & \pm & 82 & 6576 & \pm & 109 & 95683 & \pm & 857 & 70472 & \pm & 1097 & $750-9870$ & $b, c, g$ & $7300-57500$ \\
\hline $\mathrm{Fe}$ & $\mathrm{mg} / \mathrm{kgTS}$ & 547 & \pm & 33 & 2934 & \pm & 38 & 2539 & \pm & 82 & 297 & \pm & 22 & 21142 & \pm & 182 & 5251 & \pm & 84 & $477-3567$ & $b, c, g$ & $1600-268000$ \\
\hline As & $\mathrm{mg} / \mathrm{kgTS}$ & 12.7 & \pm & 0.5 & 13.56 & \pm & 0.3 & 6.8 & \pm & 0.3 & 2.41 & \pm & 0.13 & 18.42 & \pm & 0.27 & 5.69 & \pm & 0.10 & $0-287$ & $a, b, c, f, g$ & $2.8-1153$ \\
\hline $\mathrm{Cd}$ & $\mathrm{mg} / \mathrm{kgTS}$ & 0.19 & \pm & 0.07 & 0.158 & \pm & 0.019 & 0.18 & \pm & 0.02 & 1.3 & \pm & 0.4 & 0.77 & \pm & 0.05 & 0.10 & \pm & 0.01 & $0-1.42$ & $a, b, c, d, e, f, g$ & $0.12-341$ \\
\hline $\mathrm{Cr}$ & $\mathrm{mg} / \mathrm{kgTS}$ & 15.9 & \pm & 0.9 & 970.2 & \pm & 14.9 & 152.43 & \pm & 1.15 & 3.9 & \pm & 0.5 & 96.4 & \pm & 5.0 & 7.0 & \pm & 0.5 & $1-1190$ & $a, b, c, f, g$ & $13-160$ \\
\hline $\mathrm{Cu}$ & $\mathrm{mg} / \mathrm{kgTS}$ & 5.6 & \pm & 0.7 & 24.6 & \pm & 0.4 & 19.43 & \pm & 2.11 & $4.23^{*}$ & \pm & 0.14 & 33.97 & \pm & 2.27 & 7.6 & \pm & 0.4 & $3.5-26$ & $b, c, e, f, g$ & $13-219$ \\
\hline $\mathrm{Hg}$ & $\mu \mathrm{g} / \mathrm{kgTS}$ & $<2.4$ & \pm & - & $<2.4$ & \pm & - & $<2.4$ & \pm & - & $<2.4$ & \pm & - & 3.4 & \pm & 0.2 & 12.9 & \pm & 1.1 & $0-200$ & $a, b, c, d, e, g$ & $0-150$ \\
\hline $\mathrm{Ni}$ & $\mathrm{mg} / \mathrm{kgTS}$ & 2.8 & \pm & 0.6 & 11.4 & \pm & 0.3 & 6.9 & \pm & 0.4 & 2.46 & \pm & 0.26 & 43.28 & \pm & 2.13 & 10.65 & \pm & 0.26 & $4.61-147$ & $b, c, f, g$ & $8-90.2$ \\
\hline $\mathrm{Sb}$ & $\mathrm{mg} / \mathrm{kgTS}$ & 19.8 & \pm & 1.7 & 15.1 & \pm & 0.3 & 6.37 & \pm & 0.07 & 45.4 & \pm & 0.9 & 2.54 & \pm & 0.10 & 0.62 & \pm & 0.01 & $6-81.2$ & $b, g$ & $0.5-6.07$ \\
\hline Sn & $\mathrm{mg} / \mathrm{kgTS}$ & 19.4 & \pm & 1.0 & 32.9 & \pm & 0.8 & 15.8 & \pm & 0.1 & $2.12^{*}$ & \pm & 0.08 & 15.6 & \pm & 0.5 & 2.0 & \pm & 0.1 & $7.14-21$ & $b, g$ & $7.52-27$ \\
\hline $\mathrm{Nd}$ & $\mathrm{mg} / \mathrm{kgTS}$ & 2.68 & \pm & 0.24 & 3.5 & \pm & 0.1 & 3.9 & \pm & 0.1 & 10.3 & \pm & 0.9 & 29.0 & \pm & 0.6 & 11.4 & \pm & 0.6 & - & - & \\
\hline
\end{tabular}

\subsubsection{Waste material properties}

No significant differences in LHV, ash content and nutrients content were found between the glass samples within each waste flow (residual and source-segregated). Some potentially toxic metals could be associated with the colour of the analysed glass packaging fractions; the overall highest $\mathrm{Cr}$ concentrations (970$1190 \mathrm{mg} / \mathrm{kgTS}$ ) were found in green glass packaging samples (G2), Fe concentrations were higher in brown and green glass packaging (G3 and G2; $2540-2930 \mathrm{mg} / \mathrm{kgTS}$ ) than in clear glass packaging (G1; 448-547 mg/kgTS), and $\mathrm{Sb}$ concentrations were higher in clear glass packaging (G1; 19.8-26.9 mg/kgTS) than in brown and green glass packaging (G3 and G2; 6.4-15.7 mg/kgTS). In fact many potentially toxic metals and trace elements have reportedly been used to adjust colour and other optical properties of glass (De Jong et al., 2011), suggesting that glass itself is a possible source of certain potentially toxic metals in non-hazardous household waste. Higher concentrations of $\mathrm{As}, \mathrm{Ba}, \mathrm{Be}, \mathrm{Cu}, \mathrm{Sb}, \mathrm{Ga}, \mathrm{Ce}, \mathrm{Nd}$, and $\mathrm{Sb}$ were found in non-packaging glass samples (G4, $\mathrm{G} 5)$ than in the packaging glass samples.

The analysed inert fractions differed significantly with respect to many chemical properties. Ashes (i2) presented significantly higher contents of $\mathrm{P}$ and $\mathrm{Mn}$ than the other inert fractions. Ceramics (i1) and cat litter (i3) presented higher contents of $\mathrm{Al}, \mathrm{Be}, \mathrm{Co}, \mathrm{Ge}, \mathrm{Fe}, \mathrm{Hg}, \mathrm{Nb}, \mathrm{Pb}, \mathrm{Th}$, and $\mathrm{U}$ and many REE than the other glass and inert fractions. The REE concentrations in ceramics (i1; e.g. Ce: $72 \mathrm{mg} / \mathrm{kgTS}$; and $\mathrm{Nd}$ : $29.0 \mathrm{mg} / \mathrm{kgTS}$ ) were 
furthermore higher than in any other analysed waste fraction. This suggests certain mineral raw materials as a possible source of REE in non-hazardous household waste fractions. Previously REE in municipal solid waste have been typically associated with a presence of misplaced electronic waste (Morf et al., 2013).

\subsubsection{Residual versus source-segregated waste}

The results for $\mathrm{LHV}$, ash content, $\mathrm{C}$ and $\mathrm{H}$ content indicate that the organic matter content in glass samples from residual waste was considerably higher than in the samples from source-segregated waste. This suggests cross-contamination with organic materials in the residual waste flow. However, no difference in nutrient and trace element concentrations was found. Interestingly the Sr content in all source-segregated glass packaging samples was significantly higher than in the samples from residual waste, which suggests that different products were disposed of in the source-segregated waste and in the residual waste. Significantly higher contents of $\mathrm{Cu}, \mathrm{Ge}, \mathrm{Ir}, \mathrm{Mg}, \mathrm{Zn}, \mathrm{REE}$ and precious metals were found in the source-segregated kitchen and table ware glass (G4) than in the residual one. Considering that non-packaging glass was mistakenly discarded in source-segregated waste and thus a rather small amount of this fraction was found there, these differences are likely due to variation of the discarded products.

The inert sample gravel, sand and stone (i4) from residual waste presented significantly higher $\mathrm{C}, \mathrm{H}, \mathrm{Cl}, \mathrm{K}, \mathrm{Al}$, $\mathrm{Fe}, \mathrm{Ca}, \mathrm{Hg}, \mathrm{REE}$ and precious metal contents and significantly lower contents of ash, $\mathrm{Au}, \mathrm{Ca}, \mathrm{Co}, \mathrm{Pb}, \mathrm{Rh}, \mathrm{Sn}$ and $\mathrm{Ta}$ than the corresponding fraction in source-segregated waste. The result for the $\mathrm{C}$ and $\mathrm{H}$ content could possibly point towards a cross-contamination with organic material in the sample from residual waste. But general conclusions on potentially toxic metals and trace elements are not meaningful considering the very small amounts of gravel, sand and stone found in the source-segregated waste, because a sheer difference between the discarded items is very likely.

\subsubsection{Key aspects for the waste material fractioning}

The results of the physico-chemical analysis of glass waste fractions revealed considerable differences in the concentration of potentially toxic metals and trace elements dependent on the glass application (packaging or non-packaging) and the colour of glass packaging. In fact non-packaging glass is considered an impurity for the glass packaging recycling process as it disturbs the material structure and sorting the cullets by colour is important to achieve the desired colour and clarity in the remanufactured glass and glass from non-packaging applications is an undesired impurity (Baeyens et al., 2010b; Worell and Reuter, 2014). Distinguishing glass waste fractions by these characteristics (function and colour) is thus important if the waste composition data shall be applicable for assessment of systems including glass recycling.

The properties of the analysed inert samples differed significantly thus a basic distinction appears to make sense. However, considering the small amounts of ashes (i2), and gravel, sand and stone (i4) which were found in the collected household waste (especially in the source-segregated flow) were most likely not representing the full variety of materials matching this fraction.

\section{Implications and use of the dataset}

The physico-chemical properties of the investigated material fractions revealed that non-packaging application materials made of plastic, metal and glass often included higher concentrations of potentially toxic metals and trace elements than respective packaging fractions. This suggests that focusing source-segregation schemes for household waste on packaging materials, similarly to the green dot schemes as implemented in many EU 
member states (but not in Denmark), can be useful in order to minimize potentially toxic metal and trace metal contents of recyclables.

High concentrations of specific metals could be identified as intrinsic properties of certain recyclable waste materials, e.g. Sb in PET packaging, and $\mathrm{Cr}$ in green glass. Depending on the specific recycling routes this may, however, not directly result in an environmental problem. Thus, individual sub-fractions in waste material types and their routing through recycling processes have to be considered when assessing resource quality of waste materials. High metal contents should not be a priori interpreted as impurity or bad resource-quality, but should be carefully evaluated for the specific waste material flow.

For many elements significant differences were found between material fractions from residual and from source-segregated waste. The results for several paper, plastic, metal and glass waste fractions indicated crosscontamination with organic material. The results for metals and trace elements were, however, more complex; for some fractions higher metal contents were found in source-segregated than in residual waste samples. The observed differences were most likely a combined effect of more factors than just cross-contamination, e.g. disposal of different product types in residual and source-segregated waste, and "natural" variability. The assumption that source-segregated recyclables would have per se lower concentrations of metals and trace elements because cross-contamination would be widely avoided cannot be confirmed unconditionally based on the results of this study. Instead, different disposal behaviour may lead to selective disposal of critical product types in source-segregated waste. Some recyclable fractions found in source-segregated waste were of special concern: non-labelled plastic packaging (overall highest $\mathrm{Cd}$ content), and paper and cardboard composite (very high $\mathrm{Hg}$ concentrations). The differences between residual and source-segregated material fractions should be further investigated and considered when assessing recycling chains and resource quality.

Rare earth elements (REE) were detected in all analysed waste fractions, and high REE concentrations were associated with high ash contents and fractions containing soil or mineral raw materials, such as ceramics, cat litter and humus. REE in MSW have been typically associated with the presence of electronic waste (Morf et al., 2013), which should in many countries be collected separately. The measured REE concentrations were too low to represent any prospect for recovery, but the provided quantitative data suggest natural background levels in non-hazardous waste material fractions, which should be considered when discussing effectiveness of management schemes for electronic waste and dissipative usage of REE.

\section{Conclusions}

A consistent dataset for 74 physico-chemical properties of 49 material fractions in residual waste and 26 material fractions in source-segregated waste was obtained and is now available for modelling and assessment of waste management systems. Significant differences of the physico-chemical properties between waste material in residual and source-segregated waste were found. While parameters associated with organic matter were generally higher in samples from residual waste than from source-segregated waste, the results for metal and trace elements were more complex and do not allow direct conclusions on cross-contamination, as also other factors may have played a role. For many materials non-packaging fractions had higher content of impurities than complementary packaging fractions and specific subfractions of recyclable material types were shown to be highly concentrated sources for contaminants. Thus, waste management planning aiming at improved resource quality requires investigations and considerations on a very detailed fractional level. REE were present in all analysed material fractions and especially high concentrations were found in ceramics, cat litter, soil material and non-packaging glass. 


\section{Acknowledgements}

The work was supported by the Danish Strategic Research Council via the IRMAR grant (Integrated Resource Management \& Recovery, project No. 11-116775) and the 3R Research School. The authors would like to thank Sinh Nguyen, Susanne Kruse, Mona Refstrup, Erica Key and Michael Emil Olsson (DTU Environment) for their contributions to the chemical analysis.

\section{Appendices}

The excel file in the appendix contains four different sheets: i) mean values (sheet "mean"), ii) standard deviation (sheet "STDEV"), iii) number of replicates (sheet " $n \_$replicates"), iv) number of replicates below the detection limit (sheet " $\angle D L$ "), and detection limits (sheet " $D L$ "). All excel sheets present the information in a similar matrix with analysed fractions in rows and physico-chemical parameters in columns. Thus, an entry in a particular cell in each sheet refers to the same sample, while the sheets represent different layers of related information.

\section{References}

ADEME (French environment and energy management agency), 2007. La composition des ordures ménagères et assimilées en France. Agence de l'Environnement et de la Maitrisse de l'Energie

Andersen, J.K., Boldrin, A., Christensen, T.H., Scheutz, C., 2011. Mass balances and life cycle inventory of home composting of organic waste. Waste Manag. 31, 1934-42. doi:10.1016/j.wasman.2011.05.004

ArcelorMittal, 2015. Steels for packaging - Packaging [WWW Document]. URL http://packaging.arcelormittal.com/451/459/493 (accessed 12.11.15).

Arena, U., Di Gregorio, F., 2014. A waste management planning based on substance flow analysis. Resour. Conserv. Recycl. 85, 54-66. doi:10.1016/j.resconrec.2013.05.008

Astrup, T., Fruergaard, T., Christensen, T.H., 2009. Recycling of plastic: accounting of greenhouse gases and global warming contributions. Waste Manag. Res. 27, 763-72. doi:10.1177/0734242X09345868

Auhorn, W.J., 2012. Paper and Board, 3. Chemical Additives, in: Ullmann's Encyclopedia of Industrial Chemistry. Wiley-VCH Verlag GmbH \& Co.KGaA, Weinheim. doi:10.1002/14356007.018_011

Baeyens, J., Brems, A., Dewil, R., 2010a. Recovery and recycling of post-consumer waste materials. Part 1. Generalities and target wastes (paper, cardboard and aluminum cans). Int. J. Sustain. Eng. 3, 232-245. doi:10.1080/19397038.2010.507885

Baeyens, J., Brems, A., Dewil, R., 2010b. Recovery and recycling of post-consumer waste materials. Part 2. Target wastes (glass beverage bottles, plastics, scrap metal and steel cans, end-of-life tyres, batteries and household hazardous waste). Int. J. Sustain. Eng. 3, 232-245. doi:10.1080/19397038.2010.507885

Boldrin, A., Christensen, T.H., 2010. Seasonal generation and composition of garden waste in Aarhus (Denmark). Waste Manag. 30, 551-7. doi:10.1016/j.wasman.2009.11.031

Brunner, P.H., Ernst, W.R., 1986. Alternative Methods for the Analysis of Municipal Solid Waste. Waste Manag. Res. 4, 147-160. 
Burnley, S.J., 2007. A review of municipal solid waste composition in the United Kingdom. Waste Manag. 27, 1274-85. doi:10.1016/j.wasman.2006.06.018

CEN (European Committee for Standardization), 2011. European standard EN15408: Solid recovered fuels. Methods for the determination of sulphur $(\mathrm{S})$, chlorine $(\mathrm{Cl})$, fluorine $(\mathrm{F})$ and bromine $(\mathrm{Br})$ content.

CEN (European Committee for Standardization), 2009. European Standard EN 14775: Solid biofuels Determination of ash content.

CEN (European Committee for Standardization), 2006. European standard EN15400: Solid recovered fuels. Determination of calorific value.

Clavreul, J., Guyonnet, D., Christensen, T.H., 2012. Quantifying uncertainty in LCA-modelling of waste management systems. Waste Manag. 32, 2482-95. doi:10.1016/j.wasman.2012.07.008

Dahlén, L., Lagerkvist, A., 2008. Methods for household waste composition studies. Waste Manag. 28, 1100-12. doi:10.1016/j.wasman.2007.08.014

De Jong, B.H.W.S., Beerkens, R.G.C., Nijnatten, P.A., Le Bourhis, E., 2011. Glass, 1. Fundamentals. Ullmann's Encycl. Ind. Chem. doi:10.1002/14356007

DIN (German Institute for Standardization), 2005. DIN 51900-Testing of solid and liquid fuels - Determination of the gross calorific value by the bomb calorimeter and calculation of the net calorific value.

Dodoo, A., Gustavsson, L., Sathre, R., 2014. Recycling of Lumber, in: Worrell, E., Reuter, M.A. (Eds.), Handbook of Recycling. Elsevier Inc., pp. 151-163. doi:10.1016/B978-0-12-396459-5.00011-8

Dubreuil, A., Young, S.B., Atherton, J., Gloria, T.P., 2010. Metals recycling maps and allocation procedures in life cycle assessment. Int. J. Life Cycle Assess. 15, 621-634. doi:10.1007/s11367-010-0174-5

Edjabou, M.E., Jensen, M.B., Götze, R., Pivnenko, K., Petersen, C., Scheutz, C., Astrup, T.F., 2015. Municipal solid waste composition: Sampling methodology, statistical analyses, and case study evaluation. Waste Manag. 36, 12-23. doi:10.1016/j.wasman.2014.11.009

Eisted, R., Christensen, T.H., 2011. Characterization of householdwaste in Greenland. Waste Manag. 31, 14616. doi:10.1016/j.wasman.2011.02.018

EU (The European Parliamiament and the Council of the European Union), 2008. Directive 2008/98/EC of the European Parliament and of the council of 19 November 2008 on waste and repealing certain Directives.

Fjelsted, L., Christensen, T.H., 2007. Household hazardous waste: composition of paint waste. Waste Manag. Res. 25, 502-509. doi:10.1177/0734242X07082956

García, a. J., Esteban, M.B., Márquez, M.C., Ramos, P., 2005. Biodegradable municipal solid waste: Characterization and potential use as animal feedstuffs. Waste Manag. 25, 780-787. doi:10.1016/j.wasman.2005.01.006

Gidarakos, E., Havas, G., Ntzamilis, P., 2006. Municipal solid waste composition determination supporting the integrated solid waste management system in the island of Crete. Waste Manag. 26, 668-679. doi:10.1016/j.wasman.2005.07.018

Grosse, A. V., Conway, J.B., 1958. Combustion of metals in oxygen. Ind. Eng. Chem. 50, 663-672. doi:10.1021/ie50580a040 
Gy, P., 1998. Sampling for Analytical Purposes. John Wiley \& Sons Ltd.

Hansen, T., Svärd, A., Angelidaki, I., 2003. Chemical characteristics and methane potentials of source-separated and pre-treated organic municipal solid waste. Water Sci. ... 205-208.

Jha, V.K., Hayashi, S., 2009. Modification on natural clinoptilolite zeolite for its $\mathrm{NH} 4+$ retention capacity. J. Hazard. Mater. 169, 29-35. doi:10.1016/j.jhazmat.2009.03.052

Kikuchi, R., Kukacka, J., Raschman, R., 2008. Grouping of mixed waste plastics according to chlorine content. Sep. Purif. Technol. 61, 75-81. doi:10.1016/j.seppur.2007.10.001

Komilis, D., Evangelou, A., Giannakis, G., Lymperis, C., 2012. Revisiting the elemental composition and the calorific value of the organic fraction of municipal solid wastes. Waste Manag. 32, 372-81. doi:10.1016/j.wasman.2011.10.034

Kost, T., 2001. Brennstofftechnische Characterisierung von Haushaltsabfällen (Fuel characteristics of household waste), PhD Thesis. Technische Universität Dresden (Germany).

la Cour Jansen, J., Spliid, H., Hansen, T.L., Svärd, A., Christensen, T.H., 2004. Assessment of sampling and chemical analysis of source-separated organic household waste. Waste Manag. 24, 541-9. doi:10.1016/j.wasman.2004.02.013

Lagerkvist, A., Ecke, H., Christensen, T.H., 2011. Waste Generation and Characterization Waste Characterization : Approaches and Methods. Solid waste Technol. Manag. 63-84.

Laurent, A., Clavreul, J., Bernstad, A., Bakas, I., Niero, M., Gentil, E., Christensen, T.H., Hauschild, M.Z., 2014. Review of LCA studies of solid waste management systems - Part II: Methodological guidance for a better practice. Waste Manag. 34, 589-606. doi:10.1016/j.wasman.2013.12.004

Lebersorger, S., Schneider, F., 2011. Discussion on the methodology for determining food waste in household waste composition studies. Waste Manag. 31, 1924-33. doi:10.1016/j.wasman.2011.05.023

Loferski, J.R., 1999. Technologies for Wood Preservation in Historic Preservation. Arch. Museum Informatics 13, 273-290.

Ma, W., Hoffmann, G., Schirmer, M., Chen, G., Rotter, V.S., 2010. Chlorine characterization and thermal behavior in MSW and RDF. J. Hazard. Mater. 178, 489-98. doi:10.1016/j.jhazmat.2010.01.108

Matsuto, T., Ham, R.K., 1990. Residential solid waste generation and recycling in the USA and Japan. Waste Manag. Res. 8, 229-242.

Maystre, L.Y., Viret, F., 1995. A Goal-Oriented Characterization of Urban Waste. Waste Manag. Res. 13, 207218. doi:10.1177/0734242X9501300303

Miranda, R., Monte, M.C., Blanco, A., 2013. Analysis of the quality of the recovered paper from commingled collection systems. Resour. Conserv. Recycl. 72, 60-66. doi:10.1016/j.resconrec.2012.12.007

Morf, L.S., Gloor, R., Haag, O., Haupt, M., Skutan, S., Di Lorenzo, F., Böni, D., 2013. Precious metals and rare earth elements in municipal solid waste--sources and fate in a Swiss incineration plant. Waste Manag. 33, 634-44. doi:10.1016/j.wasman.2012.09.010

Noehammer, H.C., Byer, P.H., 1997. Effect of design variables on participation in residential curbside recycling programs. Waste Manag. Res. 15, 407-427. doi:10.1177/0734242X9701500408 
Petersen, L., Dahl, C.K., Esbensen, K.H., 2004. Representative mass reduction in sampling-a critical survey of techniques and hardware. Chemom. Intell. Lab. Syst. 74, 95-114. doi:10.1016/j.chemolab.2004.03.020

Pivnenko, K., Eriksson, E., Astrup, T.F., 2015a. Waste paper for recycling: Overview and identification of potentially critical substances. Waste Manag. doi:10.1016/j.wasman.2015.02.028

Pivnenko, K., Pedersen, G. a., Eriksson, E., Astrup, T.F., 2015b. Bisphenol A and its structural analogues in household waste paper. Waste Manag. 44, 39-47. doi:10.1016/j.wasman.2015.07.017

Pivnenko, K., Olsson, M.E., Götze, R., Eriksson, E., Astrup, T.F., 2016. Quantification of chemical contaminants in the paper and board fractions of municipal solid waste. Waste Manag. 51, 43-54. doi:10.1016/j.wasman.2016.03.008

Reijnders, L., Soret, S., 2003. Quantification of the environmental impact of different dietary. Am. J. Clin. Nutr. 78, 664-668.

Riber, C., Petersen, C., Christensen, T.H., 2009. Chemical composition of material fractions in Danish household waste. Waste Manag. 29, 1251-7. doi:10.1016/j.wasman.2008.09.013

Richard, T.L., Woodburry, P.B., 1992. The Impact of seperation on Heavy metal contaminants in municipal solid waste compost. Biomass and Bioernergy 3, 195-211.

RIVM (Dutch national institute of public health and the environment), 1999. Chemische analyse van huishoudelijk restafval-Resultaten 1994 en 1995 (Chemical analysis of household residual waste- results 1994 and 1994). Rijksinstituut voor volksgezondheid en milieu.

Robey, P.G., Boskey, A.L., 2009. The Composition of Bone, in: Rosen, C.J., Compston, J.E., Lian, J.B. (Eds.), ASBMR Primer on the Metabolic Bone Diseases and Disorders of Mineral Metabolism. John Wiley \& Sons, p. 537.

Robinson, V.C., Bergfeld, W.F., Belsito, D. V, Hill, R. a, Klaassen, C.D., Marks, J.G., Shank, R.C., Slaga, T.J., Snyder, P.W., Alan Andersen, F., 2010. Final report of the amended safety assessment of sodium laureth sulfate and related salts of sulfated ethoxylated alcohols. Int. J. Toxicol. 29, 151S-61S. doi:10.1177/1091581810373151

Rotter, V.S., 2002. Schwermetalle in Haushaltsabfällen (Heavy metals in household waste), PhD Thesis. Technische Universität Dresden (Germany).

Schwanecke, R., 1976. Formeln und Hilfsmonogramme für die Anwendung der Technischen Anleitung zur Reinhaltung der Luft (TAL) (Formulas and monograms for use of the technical guide for air pollution control; in German). Wasser, Luft und Betr. 20, 607.

Skutan, S., Aschenbrenner, P., 2012. Analysis of total copper, cadmium and lead in refuse-derived fuels (RDF): study on analytical errors using synthetic samples. Waste Manag. Res. 30, 1281-9. doi:10.1177/0734242X12462276

Slagstad, H., Bratteb $\varnothing$, H., 2013. Influence of assumptions about household waste composition in waste management LCAs. Waste Manag. 33, 212-9. doi:10.1016/j.wasman.2012.09.020

Summers, J.W., 1997. A review of vinyl technology. J. Vinyl Addit. Technol. 3, 130-139. doi:10.1002/vnl.10179

Sundberg, C., Franke-Whittle, I.H., Kauppi, S., Yu, D., Romantschuk, M., Insam, H., Jönsson, H., 2011. Characterisation of source-separated household waste intended for composting. Bioresour. Technol. 102, 
2859-67. doi:10.1016/j.biortech.2010.10.075

The Danish Government, 2013. Denmark without waste. Recycle more-incinerate less. doi:978-87-03026-59-5

Turconi, R., Butera, S., Boldrin, A., Grosso, M., Rigamonti, L., Astrup, T., 2011. Life cycle assessment of waste incineration in Denmark and Italy using two LCA models. Waste Manag. Res. 29, S78-S90. doi:10.1177/0734242X11417489

US EPA, 2007. US EPA Method 7473 -Mercury in solids and solutions by thermal decomposition, amalgamation, and atomic absorption spectrophotometry.

Van Roosmalen, G.R.E.M., Lustenhouwer, J.W.A., Oosthoek, J., Senden, M.M.G., 1987. Heavy metal sources and contamination mechanisms in compost production. Resour. Conserv. 14, 321-334. doi:10.1016/01663097(87)90032-0

Veeken, A., Hamelers, B., 2002. Sources of $\mathrm{Cd}, \mathrm{Cu}, \mathrm{Pb}$ and $\mathrm{Zn}$ in biowaste. Sci. Total Environ. 300, 87-98.

Westerhoff, P., Prapaipong, P., Shock, E., Hillaireau, A., 2008. Antimony leaching from polyethylene terephthalate (PET) plastic used for bottled drinking water. Water Res. 42, 551-556. doi:10.1016/j.watres.2007.07.048

Worell, E., Reuter, M.A., 2014. Handbook of recycling: state-of-the-art for practitioners, analysts, and scientists. Elsevier Inc., Waltham, USA.

WRAP, 2010. Food waste Chemical Analysis- Final Report.

Wypych, G., 2008. PVC degradation \& stabilization. ChemTec Publishing, Ontario, Canada.

Zhou, H., Meng, A., Long, Y., Li, Q., Zhang, Y., 2014. An overview of characteristics of municipal solid waste fuel in China: Physical, chemical composition and heating value. Renew. Sustain. Energy Rev. 36, 107-122. doi:10.1016/j.rser.2014.04.024 